\title{
Microphytobenthos and benthic macroalgae determine sediment organic matter composition in shallow photic sediments
}

\author{
A. K. Hardison ${ }^{1, *}$, E. A. Canuel ${ }^{1}$, I. C. Anderson ${ }^{1}$, C. R. Tobias ${ }^{2}$, B. Veuger ${ }^{3}$, and M. N. Waters ${ }^{4}$ \\ ${ }^{1}$ Virginia Institute of Marine Science, College of William \& Mary, P.O. Box 1346, Gloucester Point, VA 23062, USA \\ ${ }^{2}$ Department of Marine Sciences, University of Connecticut, Groton, CT 06340, USA \\ ${ }^{3}$ The Royal Netherlands Institute for Sea Research (NIOZ), Yerseke, the Netherlands \\ ${ }^{4}$ Valdosta State University, Valdosta, GA 31698, USA \\ * current address: University of Texas Marine Science Institute, 750 Channel View Dr., Port Aransas, TX 78373, USA
}

Correspondence to: A. K. Hardison (amber.hardison@utexas.edu)

Received: 7 January 2013 - Published in Biogeosciences Discuss.: 15 February 2013

Revised: 30 May 2013 - Accepted: 19 June 2013 - Published: 20 August 2013

\begin{abstract}
Microphytobenthos and benthic macroalgae play an important role in system metabolism within shallow coastal bays. However, their independent and interactive influences on sediment organic matter (SOM) are not well understood. We investigated the influence of macroalgae and microphytobenthos on SOM quantity and quality in an experimental mesocosm system using bulk and molecular level (total hydrolyzable amino acids, THAA; phospholipid linked fatty acids, PLFA; pigment) analyses. Our experiment used an incomplete factorial design made up of two factors, each with two levels: (1) light (ambient vs. dark) and (2) macroalgae (presence vs. absence of live macroalgae). Over the course of the 42-day experiment, total organic carbon (TOC) and total nitrogen (TN) increased under ambient light by $173 \pm 14$ and $141 \pm 7 \%$, respectively, compared to in the dark ( $78 \pm 29$ and $39 \pm 22 \%)$. THAA comprised a substantial fraction of SOM ( $16 \%$ of TOC, $35 \%$ of TN) and followed TOC and TN accumulation patterns. Mole percent composition of the THAA pool indicated that SOM was composed of more labile organic material (e.g., L-glutamic acid, phenylalanine) under ambient light conditions while SOM in dark treatments was more degraded, with higher proportions of glycine and D-alanine. PLFA content, which represents viable biomass, made up $\sim 1 \%$ of TOC and contained high levels of algal fatty acids in the light, particularly PLFA derived from diatoms. In the presence of microphytobenthos (i.e., light and macroalgae treatments), SOM lability increased, resulting in the observed increases in bacterial PLFA concentrations. Macroalgae, which were added
\end{abstract}

to half of the light treatments, decreased SOM accumulation compared to light treatments without macroalgae, with TOC and TN increasing by only $130 \pm 32$ and $94 \pm 24 \%$, respectively. This decrease likely resulted from shading by macroalgae, which reduced production of microphytobenthos. The presence of macroalgae decreased SOM lability as well, which resulted in diminished buildup of bacterial biomass. By the final day of the experiment, principal component analysis revealed that sediment composition in treatments with macroalgae was more similar to dark treatments and less similar to light treatments without macroalgae. Overall, microphytobenthos and benthic macroalgae fundamentally altered SOM quality and quantity, which may have notable ecological consequences for shallow-water systems such as increased hypoxia/anoxia, sulfide accumulation, enhanced mineralization and/or stimulated denitrification.

\section{Introduction}

Shallow coastal bays make up approximately $13 \%$ of the world's coastline, are among the most highly productive ecosystems on earth, and are distinctly vulnerable to effects from the growing problem of nutrient over-enrichment due to increased human activities (Nixon, 1995; NRC, 2000; Pedersen et al., 2004). One consequence of nutrient loading to many of these systems has been a shift in primary producer community structure. Because much of the sediment surface resides within the euphotic zone in these bays, 
benthic autotrophs often are the dominant primary producers. Observations from a number of systems have shown that as nutrient loading increases, ephemeral macroalgae, phytoplankton, and epiphytes increase, while slow-growing perennial macrophytes such as seagrasses decrease (Valiela et al., 1992; Hauxwell et al., 2001; Duarte, 1995; SandJensen and Borum, 1991). In Waquoit Bay, MA, for example, ephemeral populations of green (Cladophora) and red (Gracilaria) macroalgae replaced Zostera marina seagrass when nutrient loadings increased six-fold (Hauxwell et al., 2003). The mechanisms underlying this shift in community structure relate to differences among plant types in nutrient uptake and growth strategies (Sand-Jensen and Borum, 1991; Nielsen et al., 1996). Microphytobenthos, including benthic microalgae (e.g., diatoms) and cyanobacteria, often contribute significantly to primary production within these shallow systems; however, their response as the autotrophic community structure shifts in the face of nutrient over-enrichment is not well understood.

The dominant plants in a community greatly affect both the physical and biological conditions of a system, including overall community structure (Orth et al., 1984; Heck et al., 2003; Norkko, 1998), ecosystem processes such as nutrient cycling (Tyler et al., 2001; Risgaard-Petersen, 2003), and hydrodynamic conditions (Fonseca and Calahan, 1992; Jumars et al., 2001; Paterson and Black, 1999). For example, the presence of ephemeral macroalgae often leads to episodic anoxia and increased sulfide concentrations (Sfriso et al., 1992; Krause-Jensen et al., 1999), which negatively affect fish and benthic fauna (Norkko et al., 2000; Raffaelli et al., 1998; Gray et al., 2002) as well as other autotrophs (Hauxwell et al., 2003; Sundback and McGlathery, 2005). Macroalgae also affect other primary producers directly through shading and/or competition for nutrients. Because of their location at the sediment surface or floating just above the sediments, macroalgae may reduce the amount of light available for microphytobenthos, thereby decreasing or inhibiting microphytobenthic production (Sundback and McGlathery, 2005; Tyler et al., 2003; Valiela et al., 1997). However, some microphytobenthic communities show evidence of photo-acclimation to low-light environments and are not affected by shading by overlying macroalgal mats (Sundback and McGlathery, 2005; Sundback et al., 1996). In addition to their effects on light, macroalgae may out-compete microphytobenthos for water column nutrients, particularly when microphytobenthos are nutrient limited, which may occur in sandy sediments during warm months (Nilsson et al., 1991; Sundback and McGlathery, 2005).

Shifts in plant community structure have also been linked to changes in sediment composition (Benoy and Kalff, 1999; Kenworthy et al., 1982), which in turn affect ecosystem services like nutrient cycling and secondary production. Macrophyte canopies, for example, enhance accumulation of fine, organic-rich particles compared with unvegetated sediments (Benoy and Kalff, 1999; Gacia et al., 2002). Sediment or- ganic matter (SOM) consists of material from a variety of living and non-living sources and performs important ecosystem functions such as providing food for infauna and epifauna, aiding in sediment stability (e.g., extracellular polymeric substances produced by benthic microalgae; Wolfstein et al., 2002), and providing temporary or permanent storage for carbon (C) and nutrients (Hardison et al., 2011b; Middelburg et al., 2000). While sources contributing to SOM vary by system, microbial biomass often contributes a significant fraction of SOM in shallow systems (Volkman et al., 2008; Canuel and Martens, 1993; Bouillon and Boschker, 2006). Specifically, microphytobenthos may be a particularly good source of labile organic matter, which may support bacterial production (Volkman et al., 2008; Hardison et al., 2011b; Middelburg et al., 2000).

The objectives of this study were to examine the influence of microphytobenthos on SOM quality and quantity, and to investigate how the microphytobenthic contribution to $\mathrm{SOM}$ changes in the presence of a macroalgal bloom. Because gross measurements of SOM (e.g., total organic C, total nitrogen $(\mathrm{N})$ ) do not provide information on source and/or lability, we combined bulk and molecular-level analyses to more accurately characterize the SOM of a shallow coastal bay. Specific organic compounds (biomarkers) were used to attribute organic matter to different sources.

\section{Methods}

\subsection{Site description}

Sediments and macroalgae were collected from Hog Island Bay, Virginia (HIB), which is located along the Delmarva Peninsula and part of the Virginia Coast Reserve, a LongTerm Ecological Research (LTER) site. HIB is a shallow coastal lagoon $(<2 \mathrm{~m}$ deep at mean low water), typical of temperate lagoons along the US east coast, and is dominated by benthic autotrophs (McGlathery et al., 2001; Thomsen et al., 2006). We collected sediments and macroalgae from mid-lagoon sites where localized blooms of macroalgae have previously developed during warmer months (McGlathery et al., 2001; Thomsen et al., 2006). Throughout the rest of the year when macroalgae are less abundant, microphytobenthos dominate (McGlathery et al., 2001; Anderson et al., 2003). Additional details about the study system and complementary data from a companion stable isotope tracer study can be found in Hardison et al. (2011b).

\subsection{Experimental design}

We used a flow-through mesocosm ("perfusionator") array at the Virginia Institute of Marine Science (VIMS) Eastern Shore Laboratory (ESL) in Wachapreague, VA, that allowed for addition of nutrients simultaneously via surface water $(\mathrm{SW})$ and porewater (PW). Since nutrients are delivered to shallow coastal bays both through SW (e.g., runoff and 
atmospheric deposition) and/or PW (e.g., groundwater and sediment remineralization), it was important for our study, which focused on the community living at the sedimentwater interface, to include nutrients from both sources. Discussion of the design and testing of the perfusionator can be found in Hardison et al. (2011a). The perfusionator consisted of a $60 \mathrm{~cm}$ I.D. $\times 60 \mathrm{~cm}$ height translucent fiberglass cylinder that included a reservoir for PW at the base of the sediment column. Twelve mesocosms were filled to a depth of $\sim 15 \mathrm{~cm}$ with intact sediments extruded from cores collected from a mid-lagoon field site in May 2007. At the ESL, the mesocosms were placed in shallow water baths under shade cloth (30\% light attenuation) to control temperature and light. The water column above the sediments was stirred continuously with a mini-jet pump to keep the water column well mixed.

Nutrient-amended feed water was delivered to each perfusionator simultaneously via the SW and PW. We continuously added $\mathrm{N}$ throughout the experiment so that $\mathrm{N}$ would not limit primary production, but concentrations remained within ambient $\mathrm{N}$ levels since this was not meant to be a $\mathrm{N}$ addition study. Feed water was drawn from a creek adjacent to the ESL, pumped through a series of sand, bag $(10 \mu \mathrm{m})$, cartridge (5 and $1 \mu \mathrm{m})$, and ultraviolet filters, and amended using a high-precision metering pump with $\left(\mathrm{NH}_{4}\right)_{2} \mathrm{SO}_{4}$ in a mixing chamber before delivery to each perfusionator. $\mathrm{NH}_{4}^{+}$ was added at a rate to achieve a concentration of $25 \mu \mathrm{M}$ above background levels $(2-4 \mu \mathrm{M})$ in mesocosm SW and with minimal change to PW background levels (200-300 $\mu \mathrm{M})$. SW additions were delivered gravimetrically directly to the perfusionator water column at a rate of $\sim 43 \mathrm{Lday}^{-1}$, or a SW residence time of $\sim 2$ days. $\mathrm{PW}$ additions were delivered gravimetrically through a standpipe into the perfusionator reservoir located below the sediment column at a rate of $\sim 15 \mathrm{~L} \mathrm{day}^{-1}$, or a porewater residence time of $\sim 1.8$ days. Fine scale control of the SW and PW flow rates into each perfusionator was achieved using intravenous (IV) drippers, which were calibrated daily.

The experiment consisted of an incomplete factorial design made up of two factors, each with two levels: (1) light (ambient vs. dark) and (2) macroalgae (presence vs. absence of live macroalgae). All factors were crossed with the exception of the dark + macroalgae treatment; in order to maintain living (and growing) macroalgae, macroalgae were only added to light treatments. Each treatment was replicated $(n=4)$. Once connected to the experimental system, the mesocosms equilibrated for two weeks before beginning the experiment. During this period, the dark and light treatments were established, but macroalgae and nutrients were not added until the experiment began.

Macroalgae (Gracilaria vermiculophylla) were collected live from HIB in May 2007 and returned to the laboratory where they were cleaned of epiphytes and epifauna, rinsed with $0.7 \mu \mathrm{m}$ filtered seawater, and placed in aquaria inside a greenhouse until needed. Live macroalgae were added to half of the light treatments in densities observed naturally
(124.8 $\pm 1.6 \mathrm{gdw}^{-2}$; McGlathery et al., 2001; Hardison et al., 2010; Thomsen et al., 2006).

\subsection{Sampling}

Nutrient and macroalgal additions began on Day 0. The mesocosms were sampled prior to the additions to capture baseline conditions, and on Days 1, 3, 7, 14, 16, 21, 29 and 42. At each sampling, surface sediments $(0-1 \mathrm{~cm})$ were collected using two acrylic cores (5.7 cm I.D.) and reserved for bulk (total organic $\mathrm{C}$ (TOC), total $\mathrm{N}(\mathrm{TN})$ ), amino acid, and fatty acid analyses. Sediments from both cores were combined in pre-combusted glass jars, immediately frozen at $-20^{\circ} \mathrm{C}$, and frozen at $-80{ }^{\circ} \mathrm{C}$ within 3 days. The remaining sediment in the cores was placed carefully back into the holes in the mesocosm sediments. Sediments $(0-1 \mathrm{~cm})$ were also collected for chlorophyll $a$ concentrations using a cutoff syringe ( $1.1 \mathrm{~cm} \mathrm{I.D.),} \mathrm{placed} \mathrm{into} 15 \mathrm{~mL}$ centrifuge tubes, immediately frozen at $-20^{\circ} \mathrm{C}$, and analyzed within 1 month. Additional sediments $(0-0.3 \mathrm{~cm})$ were also collected for detailed pigment analysis using a cut-off syringe $(1.1 \mathrm{~cm} \mathrm{I.D.)}$ on a subset of the sampling days. A different region of the sediment surface was sampled each day to avoid artifacts associated with re-sampling.

Macroalgae were removed from each mesocosm, patted dry, and weighed for determination of biomass on Days 7 , $14,21,29$, and 42 . Wet mass was converted to dry mass using percent water estimates (72\%) from G. vermiculophylla collected in the field, and dry mass values were normalized to the mesocosm sediment surface area $\left(0.29 \mathrm{~m}^{2}\right)$.

\subsection{Bulk analyses}

For bulk sediment TOC and TN measurements, sediments were freeze-dried, ground and homogenized, acidified to remove inorganic C (Hedges and Stern, 1984) and analyzed using a Costech ECS 4010 elemental analyzer. Samples were analyzed for benthic chlorophyll $a$ concentrations according to a modification of the method of Lorenzen (1967; Pinckney et al., 1994). The sediment pellet was sonicated in $90 \%$ acetone, vortexed and extracted for $24 \mathrm{~h}$ at $-20^{\circ} \mathrm{C}$. The supernatant was passed through a $0.45 \mu \mathrm{m}$ CR-PTFE syringe filter and read on a Shimadzu UV-1601 UV Visible spectrophotometer $(\lambda=665,750 \mathrm{~nm})$. Chlorophyll $a$ concentrations $\left(\mathrm{mg} \mathrm{m}^{-2}\right)$ were calculated according to the equations in Lorenzen (1967). An additional set of samples was later used for detailed pigment analyses (see Sect. 2.7, below).

\subsection{Total hydrolyzable amino acids}

Hydrolyzable amino acids (HAA) were analyzed on a subset of the sediment samples according to the method presented in Veuger et al. (2005). Freeze-dried sediment ( $1 \mathrm{~g})$ was rinsed with $2 \mathrm{~N} \mathrm{HCl}$ and Milli-Q water to remove dissolved amino acids. The sediment pellet was then hydrolyzed with $6 \mathrm{~N} \mathrm{HCl}$ at $110^{\circ} \mathrm{C}$ for $20 \mathrm{~h}$. Following purification by 
cation exchange chromatography, amino acids were derivatized with isopropanol and pentafluoropropionic anhydride and further purified by solvent extraction. Concentrations of the derivatized D- and L-amino acids were measured by gas chromatography combustion isotope ratio mass spectrometry (IRMS) on a HP $6890 \mathrm{GC}$ with a Thermo type III combustion interface and a Thermo Delta Plus IRMS. The sum of concentrations of all amino acids analyzed will be referred to as total hydrolyzable amino acids (THAA). The HAAs analyzed and their major organic matter sources are presented in Table 1.

\subsection{Phospholipid linked fatty acids}

Total fatty acids were analyzed on a subset of the sediment samples according to a modified Bligh and Dyer (1959) method (Canuel et al., 2007; Poerschmann and Carlson, 2006). Wet sediments ( $\sim 12 \mathrm{~g}$ ) were extracted using an accelerated solvent extractor system (Dionex ASE 200) adapted for in-cell silica gel chromatography. Each sample was extracted twice on the ASE: neutral lipids were collected following extraction with a 9:1 $(v: v)$ hexane: acetone mixture at $50^{\circ} \mathrm{C}$, then polar lipids were collected following extraction with a $8: 2(v: v)$ methanol: chloroform solution at $80^{\circ} \mathrm{C}$. Polar lipid fractions were saponified using $\mathrm{KOH}-$ $\mathrm{CH}_{3} \mathrm{OH}$ for $2 \mathrm{~h}$ at $110^{\circ} \mathrm{C}$. Saponified samples were then extracted under basic and acidic conditions. The acid-extracted fractions were methylated with $\mathrm{BF}_{3}-\mathrm{CH}_{3} \mathrm{OH}$ to form fatty acid methyl esters (FAMEs). The polar FAMEs represented the phospholipid-linked fatty acids (PLFAs). FAME concentrations were measured by gas chromatography with flame ionization detection (GC-FID, DB-5 column, HP 5890) and quantified using methyl heneicosanoate as an internal standard. Peak identities were verified using reference standards as well as coupled gas chromatography mass spectrometry using a mass selective detector operated in electron impact mode (HP 6890, GC-MSD). Fatty acids are designated $\mathrm{A}: \mathrm{B} \omega \mathrm{C}$, where $\mathrm{A}$ is the total number of carbon atoms, $\mathrm{B}$ is the number of double bonds, and $\mathrm{C}$ is the position of the first double bond from the aliphatic " $\omega$ " end of the molecule. The prefixes "i" and " $a$ " refer to iso- and anteiso-methyl branched fatty acids (see Canuel et al., 1997 and references therein). The PLFAs analyzed and their major organic matter sources are presented in Table 1.

\subsection{Pigments}

Additional photosynthetic pigments (chlorophylls and carotenoids) were measured on a subset of the samples using a high performance liquid chromatography (HPLC) system following the methods of Leavitt and Hodgson (2001) designed specifically for sedimentary pigments. Surface sediment samples were extracted with a solvent mixture of acetone, methanol and water mixed in an $80: 15: 5$ ratio, which contained an internal standard (Sudan II; Sigma Chemical
Corp., St. Louis, MO) and allowed to extract $16-24 \mathrm{~h}$ in $\mathrm{a}-20{ }^{\circ} \mathrm{C}$ freezer. Following extraction, samples were centrifuged and filtered through a $0.22 \mu \mathrm{m}$ nylon syringe filters (Millex) to remove particulate matter. Samples were placed in an autosampler tray where they were mixed with an ionpairing agent $(0.75 \mathrm{~g}$ tetrabutyl ammonium acetate and $7.7 \mathrm{~g}$ ammonium acetate in $100 \mathrm{~mL}$ HPLC-grade water) prior to injection. $150 \mu \mathrm{L}$ of sample extract and $50 \mu \mathrm{L}$ of ion-pairing agent were injected into a Shimadzu HPLC system following the mobile phase and time sequence of Leavitt and Hodgson (2001). Chlorophyll and carotenoid pigments were separated chromatographically using a Rainin Model 200 Microsorb $\mathrm{C}_{18}$ column and measured using a photodiode array detector. Pigment identification was made using retention times of known standards (DHI Lab Products, Denmark) and pigment-specific spectra recorded by the detector. Pigment concentrations are expressed as nmol pigment $\mathrm{gdw}^{-1}$ and calculated by comparing peak areas against standards of known concentration. The pigments analyzed and their major algal sources are presented in Table 1 .

\subsection{Data analysis}

We applied repeated measures analysis of variance (ANOVA) to examine the effects of light (ambient vs. dark), macroalgae (presence vs. absence) and time (day) on the sediment parameters using the Mixed procedure in SAS 9.1 (SAS Institute Inc., Cary, NC). In all models, a compound symmetry error structure was used to model the withinsubject covariance structure. Individual HAA were analyzed on a mole percent abundance basis while individual PLFA and pigments were analyzed using concentration data. Results presented here use Type III sum of squares from the ANOVA model. Unless otherwise noted, values presented are means $\pm 1 \mathrm{SE}$ for 4 replicates.

We performed principal components analysis (PCA; Minitab 15 software) to aid in evaluating relationships between treatments and response variables. PCA is used to simplify a dataset by identifying a small set of variables that accounts for a large portion of data variance. PCA were run with data from Days 1 and 42 to explore changes in PLFA $\left(\mu \mathrm{gA} \mathrm{gdw}^{-1}\right)$ and HAA (mole \%) composition over the experiment. All HAA (11 compounds) and a sub-set of PLFA ( 9 compounds) representing all major fatty acid classes were used in the analyses. Prior to PCA, each dataset was normalized to total concentration to correct for differences in concentrations between samples (Yunker et al., 2005). Any variables that were below detection were set to 1 prior to normalization. The centered log ratio values (division by the geometric mean, followed by log transformation) were then autoscaled by dividing by the variable standard deviation. This data normalization procedure was performed to avoid artifacts of negative bias or closure associated with the dataset structure (Yunker et al., 2005). PCA loadings describe the relationships between the PC and the response variables, while 
Table 1. Specific biomarkers, abbreviations, and major organic matter sources used in this study. "Abbrev." = abbreviation.

\begin{tabular}{|c|c|c|c|}
\hline Compound group or compound & Abbrev. & Major organic matter source & References \\
\hline Phospholipid linked fatty acids & PLFA & viable or recently viable organisms & Parkes (1987) \\
\hline $\begin{array}{l}\text { Saturated fatty acids } \\
\left(\Sigma \mathrm{C}_{12}-\mathrm{C}_{30} \mathrm{FA}\right)\end{array}$ & SatFA & $\begin{array}{l}\text { mixed: general aquatic (algal and } \\
\text { microbial), higher plants }\end{array}$ & Volkman et al. (1989), Canuel and Martens (1993) \\
\hline $\begin{array}{l}\text { Monounsaturated fatty acids } \\
\left(\Sigma \mathrm{C}_{14}-\mathrm{C}_{24} \mathrm{FA}\right. \\
\text { containing } 1 \text { double bond })\end{array}$ & MUFA & algae, zooplankton, bacteria & $\begin{array}{l}\text { Volkman et al. (1986), Lee et al. (1971), } \\
\text { Gillan and Johns (1986) }\end{array}$ \\
\hline $\begin{array}{l}\text { Polyunsaturated fatty acids } \\
\left(\Sigma \mathrm{C}_{16}-\mathrm{C}_{22} \text { FA }\right. \\
\text { containing } 2+\text { double bonds) }\end{array}$ & PUFA & labile "fresh" algae & Canuel and Martens (1993) \\
\hline $\begin{array}{l}\text { Branched fatty acids } \\
\left(\Sigma \mathrm{C}_{13}-\mathrm{C}_{19} \text { branched }\right. \\
\text { odd- and even- fatty acids) }\end{array}$ & BrFA & sediment heterotrophic bacteria & Boschker et al. (2000) \\
\hline $16: 1 \omega 7$ & $16: 1 \omega 7$ & $\begin{array}{l}\text { mixed sources, including diatoms } \\
\text { and cyanobacteria }\end{array}$ & Volkman et al. (1989) \\
\hline $18: 2 \omega 6$ & $18: 2 \omega 6$ & $\begin{array}{l}\text { diatoms, possibly green algae, } \\
\text { cryptophytes }\end{array}$ & Volkman et al. (1989), Viso and Marty (1993) \\
\hline 18:4 & $18: 4$ & possibly cyanobacteria; green algae & Cook et al. (2004), Viso and Marty (1993) \\
\hline $20: 4 \omega 6$ & $20: 4 \omega 6$ & diatoms & Volkman et al. (1989) \\
\hline $20: 5 \omega 3$ & $20: 5 \omega 3$ & mainly diatoms, dinoflagellates & Viso and Marty (1993), Volkman et al. (1989) \\
\hline $22: 6 \omega 3$ & $22: 6 \omega 3$ & diatoms, dinoflagellates & Dijkman and Kromkamp (2006), Volkman et al. (1989) \\
\hline Total hydrolyzable amino acids & THAA & living and non-living organisms & $\begin{array}{l}\text { Dauwe and Middelburg (1998), } \\
\text { Pantoja and Lee (2003), Veuger et al. (2006) }\end{array}$ \\
\hline D-alanine & D-Ala & heterotrohic bacteria & Veuger et al. (2005), Pelz et al. (1998) \\
\hline L-alanine & L-Ala & general mixed & Cowie and Hedges (1992) \\
\hline Threonine + Valine & $\mathrm{Thr}+\mathrm{Val}$ & $\begin{array}{l}\text { general mixed; possibly degraded } \\
\text { organic matter }\end{array}$ & $\begin{array}{l}\text { Dauwe and Middelburg (1998), } \\
\text { Cowie and Hedges (1992) }\end{array}$ \\
\hline Glycine & Gly & $\begin{array}{l}\text { general mixed; possibly degraded } \\
\text { organic matter }\end{array}$ & $\begin{array}{l}\text { Dauwe and Middelburg (1998), } \\
\text { Cowie and Hedges (1992) }\end{array}$ \\
\hline Isoleucine & Ile & $\begin{array}{l}\text { general mixed; possibly degraded } \\
\text { organic matter }\end{array}$ & $\begin{array}{l}\text { Dauwe and Middelburg (1998), } \\
\text { Cowie and Hedges (1992) }\end{array}$ \\
\hline Leucine & Leu & $\begin{array}{l}\text { general mixed; possibly degraded } \\
\text { organic matter }\end{array}$ & $\begin{array}{l}\text { Dauwe and Middelburg (1998), } \\
\text { Cowie and Hedges (1992) }\end{array}$ \\
\hline Proline & Pro & general mixed & Cowie and Hedges (1992) \\
\hline Aspartine & Asp & general mixed & Cowie and Hedges (1992) \\
\hline L-Glutamic acid & L-Glu & $\begin{array}{l}\text { general mixed; possibly labile } \\
\text { organic matter }\end{array}$ & $\begin{array}{l}\text { Dauwe and Middelburg (1998), } \\
\text { Cowie and Hedges (1992) }\end{array}$ \\
\hline Phenylalanine & Phe & $\begin{array}{l}\text { general mixed; possibly labile } \\
\text { organic matter }\end{array}$ & $\begin{array}{l}\text { Dauwe and Middelburg (1998), } \\
\text { Cowie and Hedges (1992) }\end{array}$ \\
\hline Lysine & Lys & general mixed & Cowie and Hedges, 1992 \\
\hline \multicolumn{4}{|l|}{ Pigments } \\
\hline Chlorophyll $a$ & Chla & photosynthetic algae & Leavitt and Hodgson (2001) \\
\hline Fucoxanthin & Fuco & diatoms & Leavitt and Hodgson (2001) \\
\hline Zeaxanthin & Zea & cyanobacteria & Leavitt and Hodgson (2001) \\
\hline Lutein & Lut & green algae & Leavitt and Hodgson (2001) \\
\hline Myxoxanthophyll & Myxo & cyanobacteria & Leavitt and Hodgson (2001) \\
\hline
\end{tabular}

PCA scores describe the relationships between the PC and the treatments.

\section{Results}

\subsection{Experimental conditions}

Temperature and salinity in the mesocosm water columns were similar among treatments and to the field site (Table 2).
Macroalgae in the mesocosms grew steadily from $125 \pm 1$ to $410 \pm 102 \mathrm{gdw} \mathrm{m}^{-2}$, which was within the range observed at the HIB field sites (Fig. 1a; Table 2). Concentrations of benthic chlorophyll $a$ were higher for light treatments without macroalgae ("Light") and with macroalgae ("Macro") than for the dark treatment ("Dark"; Fig. 1b). Mean sediment TOC and TN concentrations for the mesocosms were similar to field values (Table 2). 

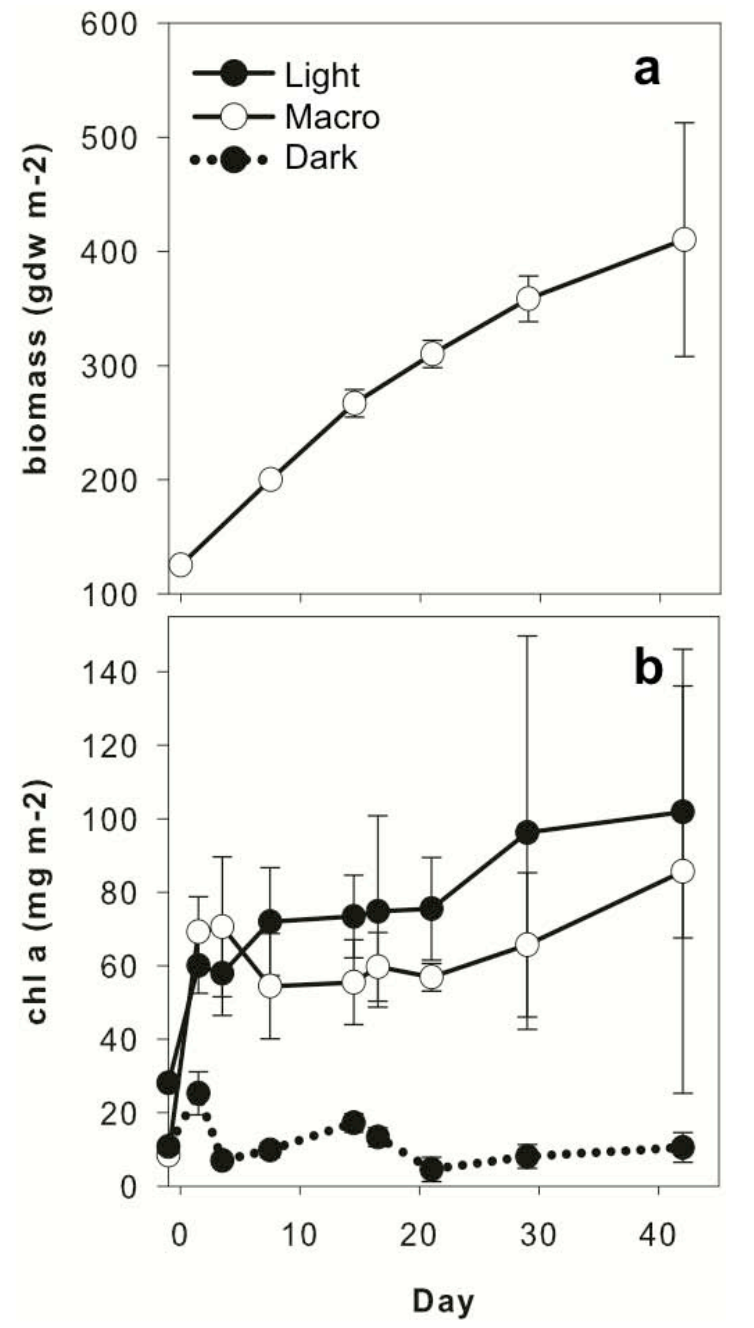

Fig. 1. Macroalgal biomass (a) and benthic chlorophyll $a$ concentrations for surface $(0-1 \mathrm{~cm})$ sediments (b). Treatments shown are light with macroalgae ("Macro"; solid lines, filled symbols), light without macroalgae ("Light"; solid lines, open symbols), and dark without macroalgae ("Dark"; dotted lines with filled symbols). Values are mean $\pm \operatorname{SE}(n=4)$.

\subsection{Bulk sediments}

Surface sediment TN and TOC concentrations followed similar patterns throughout the experiment (Fig. 2a and b; Supplement Table 1) and were highly correlated with one another ( $r=0.96,0.95$ and 0.98 for Light, Macro, and Dark treatments, respectively). TN for all samples began at $\sim 14 \mu \mathrm{mol} \mathrm{gdw}^{-1}$ and increased throughout the experiment, reaching levels (mean $\pm \mathrm{SE}$ ) of $35.2 \pm 1.0$, $28.4 \pm 5.0$, and $19.8 \pm 3.1 \mu \mathrm{mol} \mathrm{Ngdw}^{-1}$ on Day 42 for Light, Macro, and Dark treatments, respectively. TOC increased from $\sim 144 \mu \mathrm{mol} \mathrm{C} \mathrm{gdw}^{-1}$ on Day 0 to $404.0 \pm 20.6$, $340.7 \pm 67.0$, and $248.6 \pm 40.2 \mu \mathrm{molC} \mathrm{gdw}^{-1}$ for Light, Macro, and Dark treatments, respectively, on Day 42. For the Light and Dark treatments, the increases for TN and TOC

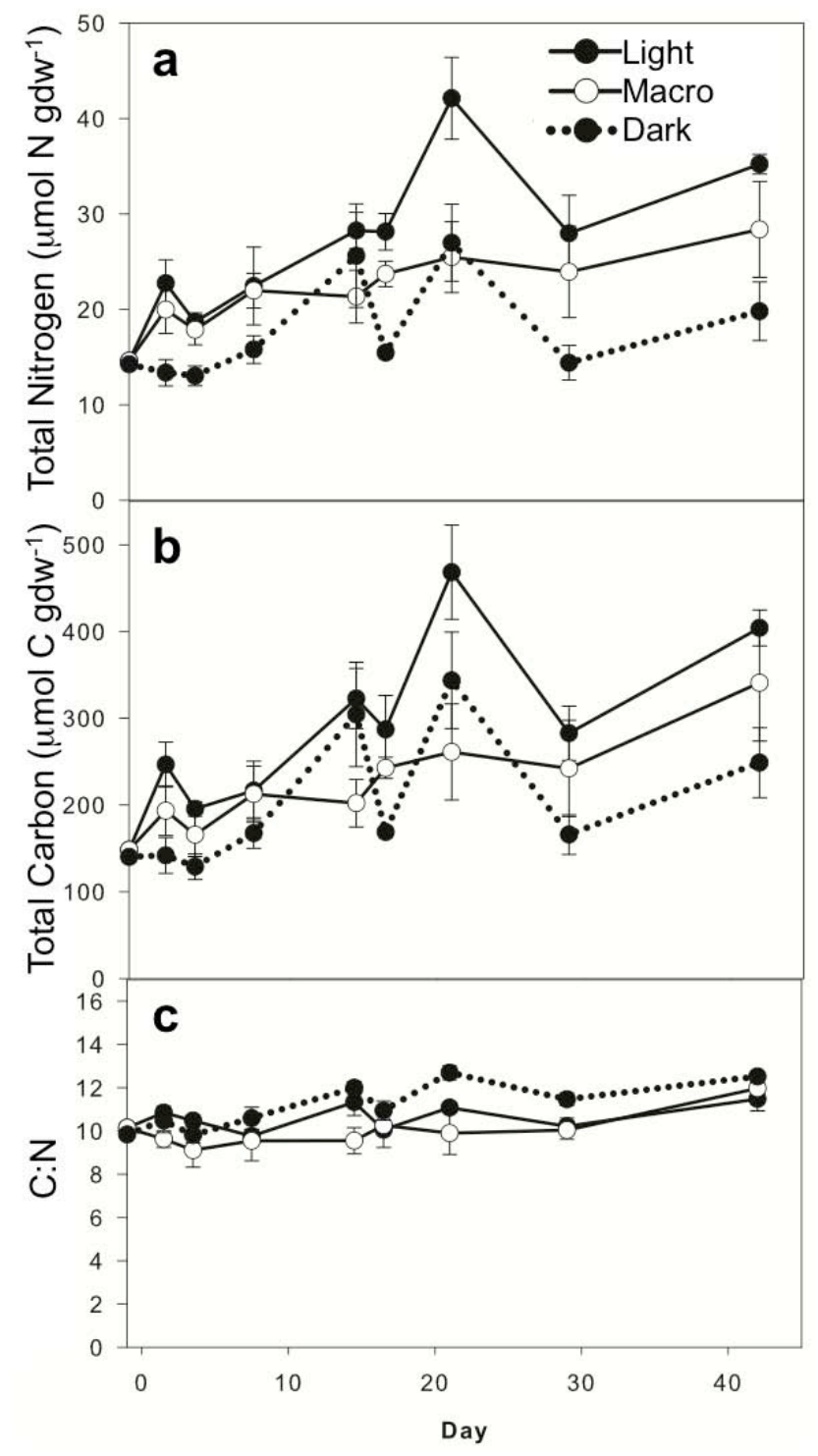

Fig. 2. Total nitrogen (a) and total organic carbon (b) concentrations and $\mathrm{C}: \mathrm{N}(\mathbf{c})$ in surface $(0-1 \mathrm{~cm})$ sediments. Values are mean $\pm \mathrm{SE}$ $(n=4)$.

were not monotonic, and both peaked on Day 21 (Fig. 2a and b). Both TN and TOC showed significant light, macroalgae, and time effects (Table 3). Light treatments had the highest $\mathrm{TN}$ and TOC concentrations; Dark had the lowest concentrations, and concentrations in Macro were intermediate. $\mathrm{C}: \mathrm{N}$ ratios remained relatively constant over time $(10.7 \pm 0.2)$ and displayed no significant light or macroalgae effects (Fig. 2c; Table 3).

Benthic chlorophyll $a$ content was highly variable over time, but generally showed the same patterns as sediment organic content (Fig. 1b). Between Day 0 and Day 42, concentrations for the Light treatments increased from 28.1 to $101.8 \pm 34.2 \mathrm{mg} \mathrm{Chl} a \mathrm{~m}^{-2}$, Macro increased from 8.4 to $85.7 \pm 60.4 \mathrm{mg} \mathrm{m}^{-2}$, and the Dark treatments 
Table 2. Parameters measured concurrently at Hog Island Bay field sites and in mesocosms. Field samples were collected from a mid-lagoon site on three dates while the mesocosm experiment was being conducted. Mesocosm values are means of daily means across all time steps. Values are presented as the mean (SE) for field $(n=5)$ and mesocosm treatments $(n=9)$.

\begin{tabular}{lllll}
\hline Parameter & Field & Light & Macro & Dark \\
\hline Temperature $\left({ }^{\circ} \mathrm{C}\right)$ & $24.1(1.6)$ & $23.6(2.9)$ & $23.9(2.9)$ & $23.7(2.8)$ \\
Salinity $(\mathrm{psu})$ & $31.4(0.6)$ & $31.6(1.3)$ & $31.5(1.3)$ & $31.0(1.0)$ \\
Macroalgal density $\left(\mathrm{gdw} \mathrm{m}^{-2}\right)$ & $59.2(30.7)$ & $\mathrm{n} / \mathrm{a}$ & $278.6(31.4)$ & $\mathrm{n} / \mathrm{a}$ \\
$\quad$ range $\left(\mathrm{gdw} \mathrm{m}^{-2}\right)$ & $0-355$ & $\mathrm{n} / \mathrm{a}$ & $124-513$ & $\mathrm{n} / \mathrm{a}$ \\
Benthic chlorophyll $a\left(\mathrm{mg} \mathrm{m}^{-2}\right)$ & $24.9(7.1)$ & $74.1(9.7)$ & $59.5(7.2)$ & $11.9(1.6)$ \\
Sediment TOC $\left(\mu \mathrm{mol} \mathrm{Cgdw}^{-1}\right)$ & $185.4(32.3)$ & $302.9(23.3)$ & $232.6(15.3)$ & $208.6(21.1)$ \\
Sediment TN $\left(\mu \mathrm{mol} \mathrm{N} \mathrm{gdw}^{-1}\right)$ & $22.3(3.1)$ & $28.2(1.9)$ & $22.8(1.0)$ & $18.1(1.5)$ \\
\hline
\end{tabular}

remained unchanged, with a mean across all samples of $11.9 \pm 4.1 \mathrm{mg} \mathrm{m}^{-2}$. Light was significantly higher than Dark (Table 3). We were unable to detect statistically significant differences between Macro and Light treatments due to high variability between mesocosms within a treatment.

\subsection{Total Hydrolyzable Amino Acids (THAA)}

THAA concentrations (Fig. 3a) showed similar patterns to sediment TOC and TN content (Fig. 2a and b; Supplement Table 1). Concentrations for all treatments increased from $\sim 4 \mu \mathrm{mol} \mathrm{AA} \mathrm{gdw} \mathrm{Ad}^{-1}$ on Day 0 to $14 \pm 1.3,8.4 \pm 1.1$, and $6.8 \pm 1.1 \mu \mathrm{mol} \mathrm{AA} \mathrm{gdw}{ }^{-1}$ on Day 21 for Light, Macro, and Dark treatments, respectively, and then concentrations remained steady through Day 42. Light treatment had the highest concentrations, Dark had the lowest, and concentrations in Macro were intermediate (Fig. 3a). THAA-C made up approximately $\sim 14 \%$ of TOC for both light (Light and Macro) treatments and $12 \%$ of TOC for Dark treatment, and THAA$\mathrm{N}$ made up approximately 39 and $33 \%$ of TN for Light and Dark treatments, respectively (Table 4).

Concentrations of four selected individual amino acids are presented as mole percentages in Fig. 4; however, data for all 11 amino acids analyzed are presented in Supplemental Table 2, and abbreviations are provided in Table 1. Across all treatments, Gly was the most abundant amino acid, making up approximately $25 \%$ of THAA, followed by L-Ala and Asp, L-Glu, Pro, Thr + Val, Leu, Lys, Ile and Phe, and D-Ala. Most amino acids showed a significant light effect, with the exception of L-Glu, Pro, and Phe (Table 3). Mole percentages of Leu, L-Ala, Thr + Val, Ile, and Lys were higher for Light than Dark, while Gly, D-Ala and Asp were higher in the Dark (Fig. 4a-d; Supplemental Table 2). The only amino acid to display a significant macroalgae effect was Lys, for which mole percentages were higher in Light treatments (Fig. 4b; Table 3).

\subsection{Phospholipid linked fatty acids (PLFA)}

PLFA concentrations (Fig. 3b) followed patterns similar to those of sediment TOC, TN, and THAA content (Figs. 2a, b

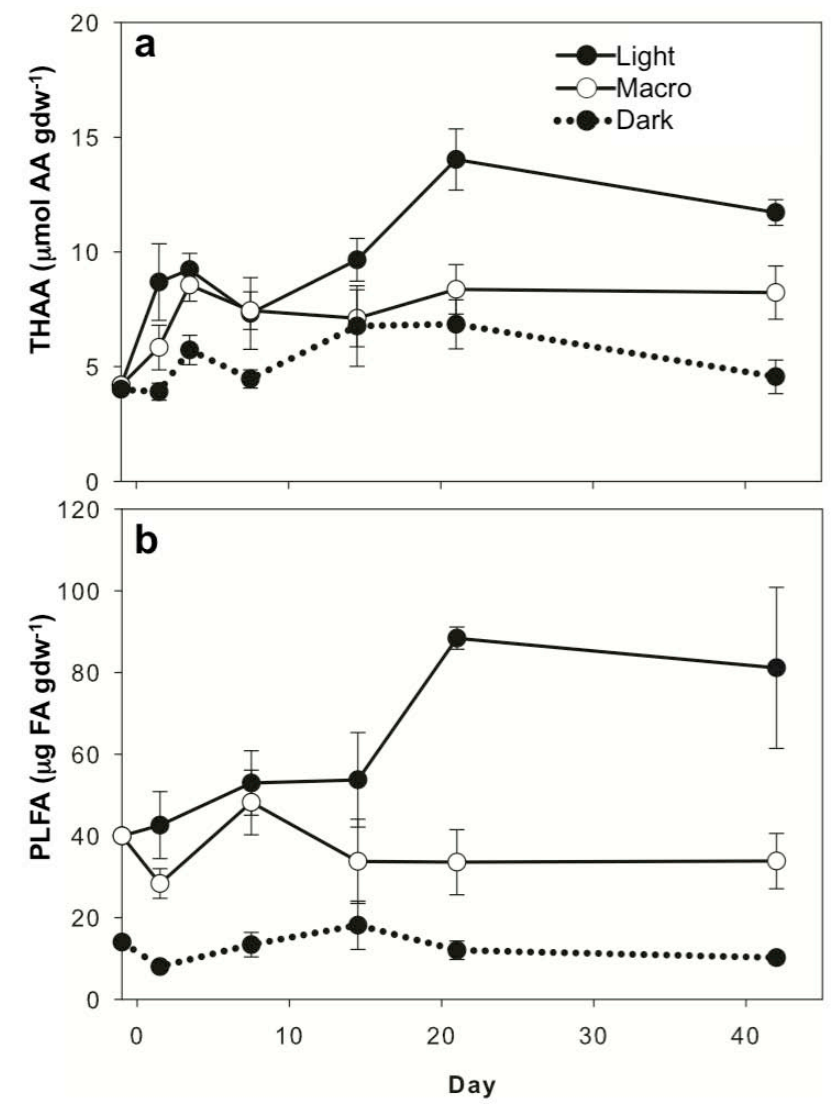

Fig. 3. THAA (a) and total PLFA (b) concentrations in surface (0$1 \mathrm{~cm})$ sediments. Values are mean $\pm \operatorname{SE}(n=4)$.

and 3a; Supplement Table 1). PLFA concentrations differed significantly across treatments, with highest concentrations in the Light treatments, lowest concentrations in Dark treatments, and intermediate concentrations in Macro treatments (Fig. 3b). PLFA-C made up a variable fraction of TOC over the course of the experiment (Table 4). The Dark treatment was lowest, decreasing from 0.6 to $0.3 \pm 0.03 \%$ of TOC from Days 0 to 42. Both Light and Macro treatments began with PLFA-C levels at $1.6 \%$ of TOC and generally decreased 
Table 3. Results of two-factor repeated measures ANOVA, which was used to test for differences in light and macroalgae over time for various sediment organic matter variables. Significant $p$ values $(<0.05)$ are indicated in bold.

\begin{tabular}{|c|c|c|c|c|c|c|c|c|c|}
\hline & \multicolumn{3}{|c|}{ Light } & \multicolumn{3}{|c|}{ Macroalgae } & \multicolumn{3}{|c|}{ Time } \\
\hline & df & $F$ & $p$ & $\mathrm{df}$ & $F$ & $p$ & $\mathrm{df}$ & $F$ & $p$ \\
\hline $\mathrm{TN}$ & 9 & 31.97 & 0.0003 & 9 & 8.73 & 0.0161 & 61 & 9.24 & $<0.0001$ \\
\hline TOC & 9 & 13.5 & 0.0051 & 9 & 7.61 & 0.0222 & 61 & 12.39 & $<0.0001$ \\
\hline$C: N$ & 9 & 2.35 & 0.1598 & 9 & 2.77 & 0.1302 & 61 & 6.02 & $<0.0001$ \\
\hline Chla & 9 & 27.65 & 0.0005 & 9 & 0.83 & 0.3849 & 61 & 0.43 & 0.8325 \\
\hline THAA & 8 & 29.94 & 0.0006 & 8 & 6.25 & 0.0369 & 38 & 4.57 & 0.0020 \\
\hline$\%$ THAA/TN & 8 & 21.59 & 0.0017 & 8 & 4.62 & 0.0638 & 38 & 20.45 & $<0.0001$ \\
\hline$\%$ THAA/TOC & 8 & 12.83 & 0.0072 & 8 & 0.71 & 0.4249 & 38 & 24.76 & $<0.0001$ \\
\hline$\%$ GLY & 8 & 13.31 & 0.0065 & 8 & 0.07 & 0.7947 & 38 & 2.19 & 0.0759 \\
\hline$\%$ LGLU & 8 & 0.05 & 0.8316 & 8 & 0.04 & 0.8561 & 38 & 1.95 & 0.1093 \\
\hline$\%$ LEU & 8 & 113.11 & $<0.0001$ & 8 & 0.08 & 0.7868 & 38 & 4.48 & 0.0026 \\
\hline$\%$ DALA & 8 & 41.44 & 0.0002 & 8 & 0.3 & 0.6000 & 38 & 2.45 & 0.0508 \\
\hline$\%$ LALA & 8 & 6.45 & 0.0347 & 8 & 0.19 & 0.6736 & 38 & 5.03 & 0.0012 \\
\hline$\% \mathrm{THR}+\mathrm{VAL}$ & 8 & 8.4 & 0.0199 & 8 & 0.33 & 0.579 & 38 & 2.55 & 0.0438 \\
\hline$\%$ ILE & 8 & 36.36 & 0.0003 & 8 & 0.71 & 0.425 & 38 & 8.29 & $<0.0001$ \\
\hline$\%$ PRO & 8 & 0.37 & 0.5583 & 8 & 2.64 & 0.1428 & 38 & 2.02 & 0.0975 \\
\hline$\%$ ASP & 8 & 7.94 & 0.0226 & 8 & 3.13 & 0.1148 & 38 & 5.67 & 0.0005 \\
\hline$\%$ PHE & 8 & 0.01 & 0.9235 & 8 & 0.06 & 0.8177 & 38 & 0.58 & 0.7173 \\
\hline$\%$ LYS & 8 & 12 & 0.0085 & 8 & 10.17 & 0.0128 & 38 & 1.83 & 0.1312 \\
\hline PLFA & 9 & 209.95 & $<0.0001$ & 9 & 54.28 & $<0.0001$ & 34 & 1.85 & 0.1424 \\
\hline$\%$ PLFA/TOC & 9 & 65.84 & $<0.0001$ & 9 & 5.18 & 0.0489 & 34 & 3.98 & 0.0094 \\
\hline SatFA & 9 & 98.43 & $<0.0001$ & 9 & 23.01 & 0.001 & 34 & 1.15 & 0.3552 \\
\hline MUFA & 9 & 202.87 & $<0.0001$ & 9 & 46.09 & $<0.0001$ & 34 & 1.72 & 0.1559 \\
\hline PUFA & 9 & 59.19 & $<0.0001$ & 9 & 19.17 & 0.0018 & 34 & 1.24 & 0.3121 \\
\hline BrFA & 9 & 17.01 & 0.0026 & 9 & 3.75 & 0.0848 & 34 & 5.37 & 0.0010 \\
\hline $16: 1 \omega 7$ & 9 & 36.25 & 0.0002 & 9 & 6.07 & 0.0359 & 34 & 1.59 & 0.1882 \\
\hline $18: 2 \omega 6$ & 9 & 19.03 & 0.0018 & 9 & 3.02 & 0.1162 & 34 & 3.11 & 0.0204 \\
\hline $18: 4$ & 9 & 23.47 & 0.0009 & 9 & 7.66 & 0.0218 & 34 & 0.73 & 0.6094 \\
\hline $20: 4 \omega 6$ & 9 & 14.34 & 0.0043 & 9 & 6.32 & 0.0331 & 34 & 1.33 & 0.2753 \\
\hline $20: 5 \omega 3$ & 9 & 109.42 & $<0.0001$ & 9 & 27.53 & 0.0005 & 34 & 1.97 & 0.1088 \\
\hline $22: 6 \omega 3$ & 9 & 47.14 & $<0.0001$ & 9 & 12.12 & 0.0069 & 34 & 2.25 & 0.072 \\
\hline $20: 5 / 18: 2$ & 9 & 27.52 & 0.0005 & 9 & 1.99 & 0.1916 & 34 & 7.35 & $<\mathbf{0 . 0 0 0 1}$ \\
\hline fuco & 9 & 22.44 & 0.0011 & 9 & 1.05 & 0.3318 & 25 & 1.01 & 0.4052 \\
\hline zea + lut & 9 & 2.07 & 0.1843 & 9 & 0.41 & 0.5361 & 25 & 2.18 & 0.1161 \\
\hline myxo & 9 & 4.79 & 0.0564 & 9 & 0.01 & 0.9174 & 25 & 4.53 & 0.0114 \\
\hline fuco/(zea + lut) & 9 & 13.85 & 0.0048 & 9 & 0.59 & 0.4622 & 25 & 4.42 & 0.0126 \\
\hline
\end{tabular}

over time. By Day 42, Light had the highest PLFA-C levels, at $1.2 \pm 0.3 \%$ of TOC, while Macro ended with PLFA-C levels of $0.6 \pm 0.002 \%$ of TOC.

Concentrations of two selected groups and five individual PLFA are presented in Fig. 5; however, data for all PLFA analyzed are presented in Supplement Table 3. Abbreviations and sources are provided in Table 1, and treatment effects are shown in Table 3. Groups of PLFA representing algal and heterotrophic bacteria sources showed the same concentration patterns over time as total PLFA (Figs. 5a, b and 3b). Saturated fatty acids (SatFA; non-specific source) were the most abundant group, making up $\sim 50 \%$ of total PLFA, followed generally by monounsaturated fatty acids (MUFA; non-specific source; 30\%), polyunsaturated fatty acids (PUFA; algal; $15 \%$ ), and branched fatty acids (BrFA; heterotrophic bacteria; $~ 5 \%$ ). PUFA and BrFA are displayed (Fig. 5a and b); however, SatFA and MUFA followed similar patterns (Supplement Table 3). All PLFA groups showed a significant light effect, with concentrations in Light treatments exceeding Dark treatments (Table 3). In addition, all groups except BrFA showed a significant macroalgae effect, with higher concentrations in the Light treatment than Macro.

Algal-specific fatty acids varied between treatments as well as over time (Fig. 5c-g; Table 3). Concentrations

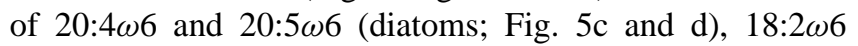




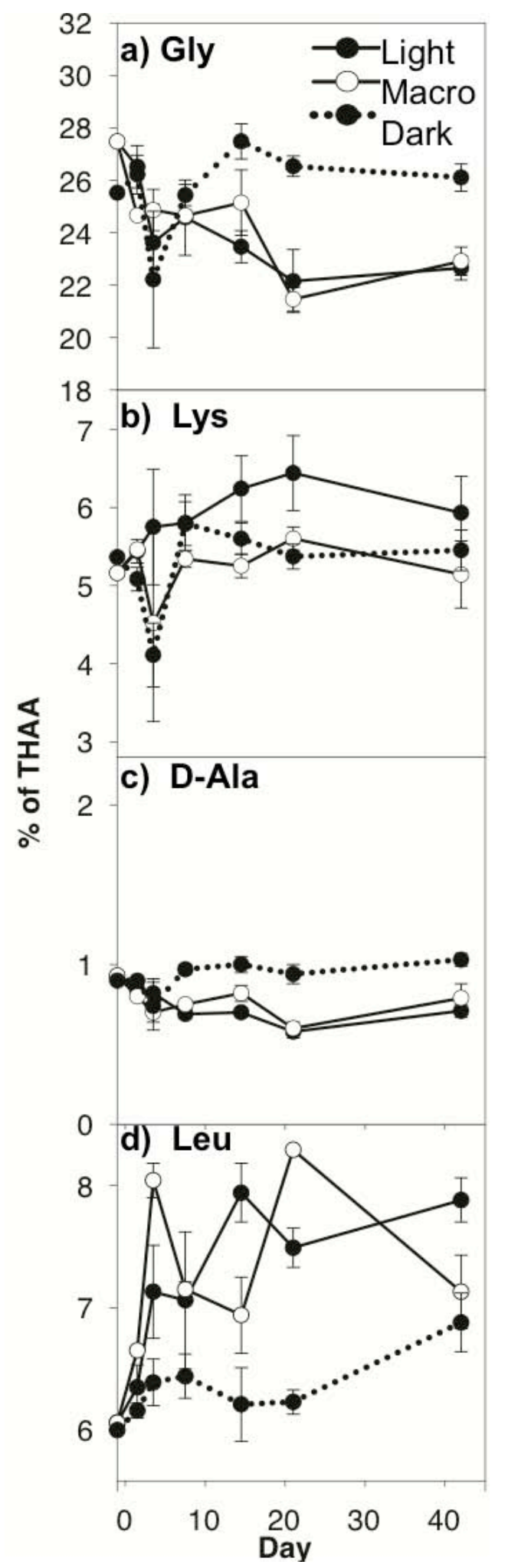

Fig. 4. Composition as mole percent of THAA for select HAA in surface $(0-1 \mathrm{~cm})$ sediments: (a) glycine, (b) lysine, (c) D-alanine, and (d) leucine. Note scale differences between graphs. Values are mean $\pm \operatorname{SE}(n=4)$.
Table 4. The proportion (\%) of PLFA/TOC, THAA/TOC and THAA/TN in sediments. Values are mean (SE). $n=4$ for all except Day $-1(n=1)$. "Treat." = treatment.

\begin{tabular}{lrrrr}
\hline Treat. & Day & PLFA/TOC & THAA/TOC & THAA/TN \\
& & $(\%)$ & $(\%)$ & $(\%)$ \\
\hline Light & -1 & 1.62 & 11.78 & 32.14 \\
& 1 & $1.02(0.14)$ & $14.86(1.99)$ & $42.37(6.32)$ \\
& 3 & $\mathrm{n} / \mathrm{a}$ & $20.82(1.44)$ & $55.58(2.91)$ \\
& 7 & $1.49(0.17)$ & $14.49(0.87)$ & $36.32(1.68)$ \\
& 14 & $1.02(0.20)$ & $13.77(1.82)$ & $38.89(2.74)$ \\
& 21 & $1.18(0.14)$ & $13.60(0.41)$ & $38.01(0.84)$ \\
Macro & 42 & $1.22(0.30)$ & $13.16(1.13)$ & $37.80(1.56)$ \\
& -1 & 1.62 & 11.78 & 32.14 \\
& 1 & $0.89(0.04)$ & $12.48(0.26)$ & $32.76(0.42)$ \\
& 3 & $\mathrm{n} / \mathrm{a}$ & $19.74(1.81)$ & $48.99(2.96)$ \\
& 7 & $1.36(0.06)$ & $13.51(1.58)$ & $35.80(0.13)$ \\
& 14 & $0.99(0.30)$ & $14.83(2.33)$ & $36.93(3.02)$ \\
& 21 & $0.79(0.10)$ & $12.28(0.33)$ & $33.30(1.02)$ \\
& 42 & $0.60(0.002)$ & $10.85(0.67)$ & $32.89(1.10)$ \\
& -1 & 0.61 & 12.43 & 31.58 \\
& 1 & $0.36(0.05)$ & $12.18(0.73)$ & $32.81(0.66)$ \\
& 3 & $\mathrm{n} / \mathrm{a}$ & $19.70(1.77)$ & $48.91(5.32)$ \\
& 7 & $0.48(0.07)$ & $11.69(0.41)$ & $32.04(0.72)$ \\
& 14 & $0.33(0.05)$ & $9.06(0.62)$ & $28.62(1.58)$ \\
& 21 & $0.21(0.04)$ & $8.61(0.32)$ & $28.40(0.61)$ \\
& 42 & $0.25(0.03)$ & $8.00(0.16)$ & $25.88(0.35)$ \\
\hline \multirow{6}{*}{ Dark } & & & &
\end{tabular}

(diatoms, possibly green algae, cryptophytes; Fig. 5e), 18:4 (possibly cyanobacteria; Fig. 5f), and 22:6 63 (diatoms, possibly dinoflagellates; Fig. 5g) followed similar patterns. All were significantly higher in the Light treatment than Dark. Among light treatments, all except 18:2 $\omega 6$ were higher in the Light than in the Macro treatment. 18:2 $\omega 6$ showed no significant macroalgae effect. Generally, $\mathrm{C}_{20}$ PUFA were more abundant than $\mathrm{C}_{18}$ PUFA, although their relative abundances, as demonstrated by the ratios of $20: 5 \omega 3 / 18: 2 \omega 6$, shifted over time (Fig. 5h). For light treatments, this ratio decreased from 5.7 to $1.9 \pm 0.5$ (Light) and $0.8 \pm 0.3$ (Macro) from Day 0 to 42 . BrFA, representing bacterial-specific fatty acids (Table 1), were also more concentrated in Light and Macro treatments, but showed no significant macroalgae effect (Fig. 5b; Table 3).

\subsection{Accessory pigments}

Concentrations of selected pigments and the ratio of fucoxanthin to the sum of zeaxanthan and lutein (fuco/(zea + lut)) are presented in Fig. 6, and treatment effects are shown in Table 3. Data for these pigments are presented in Supplementary Table 4, and abbreviations are defined in Table 1. Specific photosynthetic pigments varied between treatments as well as over time (Fig. 6a-c). Fuco (diatoms; Fig. 6a) was the most abundant accessory pigment, and was significantly higher in the Light than in the Dark. Concentrations of 

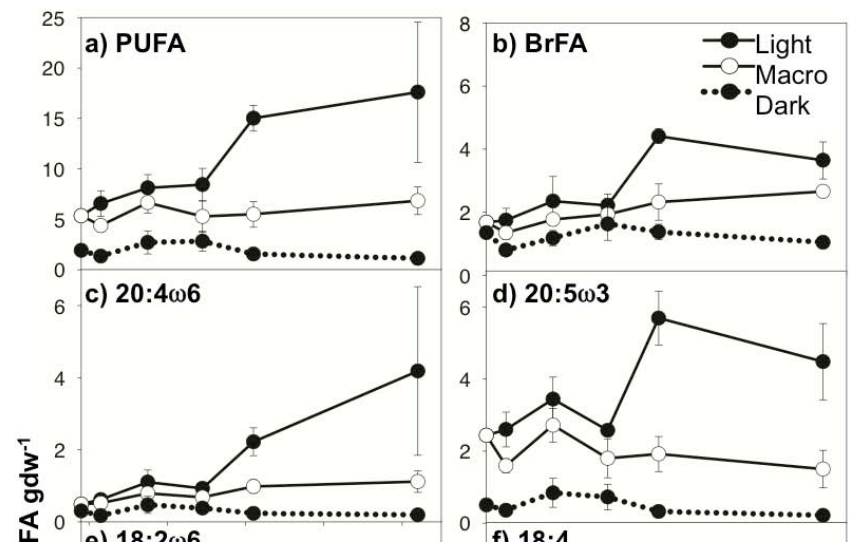

일 6
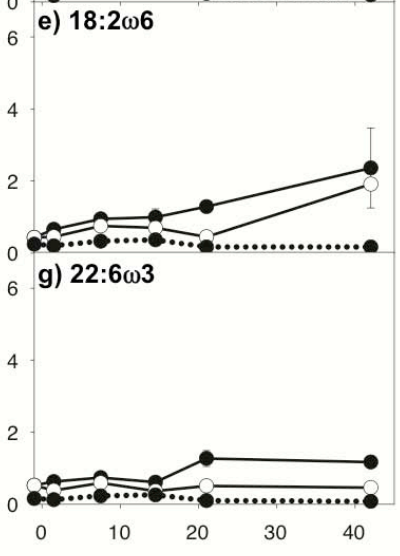
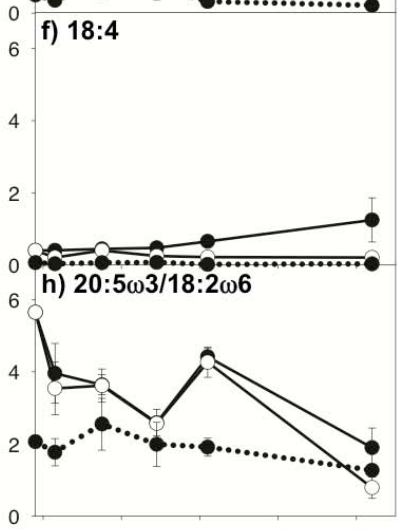
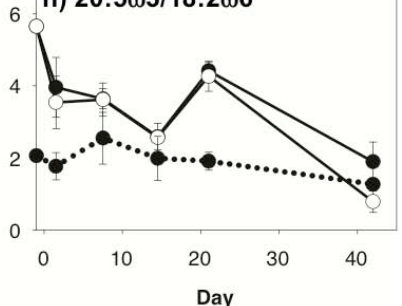

Fig. 5. Concentrations of select algal and bacterial PLFA in surface $(0-1 \mathrm{~cm})$ sediments. (a-g) are in units of $\mu \mathrm{gA} \mathrm{gdw}^{-1}$. (h) is unitless since it is a ratio of concentrations. Values are mean $\pm \mathrm{SE}$ $(n=4)$.

myxoxanthophyll (myxo, cyanobacteria; Fig. 6b) were negligible and showed no significant treatment effects. Zea + lut (green algae and cyanobacteria; Fig. 6c) were moderately abundant but showed no significant treatment effects. Although our HPLC system cannot resolve the isomers zea and lut, our analyses suggest that the peak is dominated by lut and therefore represents green algae (Leavitt and Hodgson, 2001). This is supported by a purity analysis of the peak on the HPLC chromatograms and low concentrations of other cyanobacterial pigments (myxo). None of the pigments showed a significant macroalgae effect (Table 3). Although fuco was more abundant than zea+lut, their relative abundances, as demonstrated by the ratios of fuco/(zea + lut), shifted over time (Fig. 6d). This ratio decreased from Day 0 to Day 42 from $21.1 \pm 3.7$ to $4.2 \pm 2.1$ (Light), from $21.1 \pm 7.2$ to $1.5 \pm 0.2$ (Macro) and from $21.1 \pm 0.6$ to $0.6 \pm 0.1$ (Dark).

\subsection{Principal components analysis (PCA)}

PCA provided a summary of changes in sediment composition between treatments and over time (Day 1 vs. Day 42).

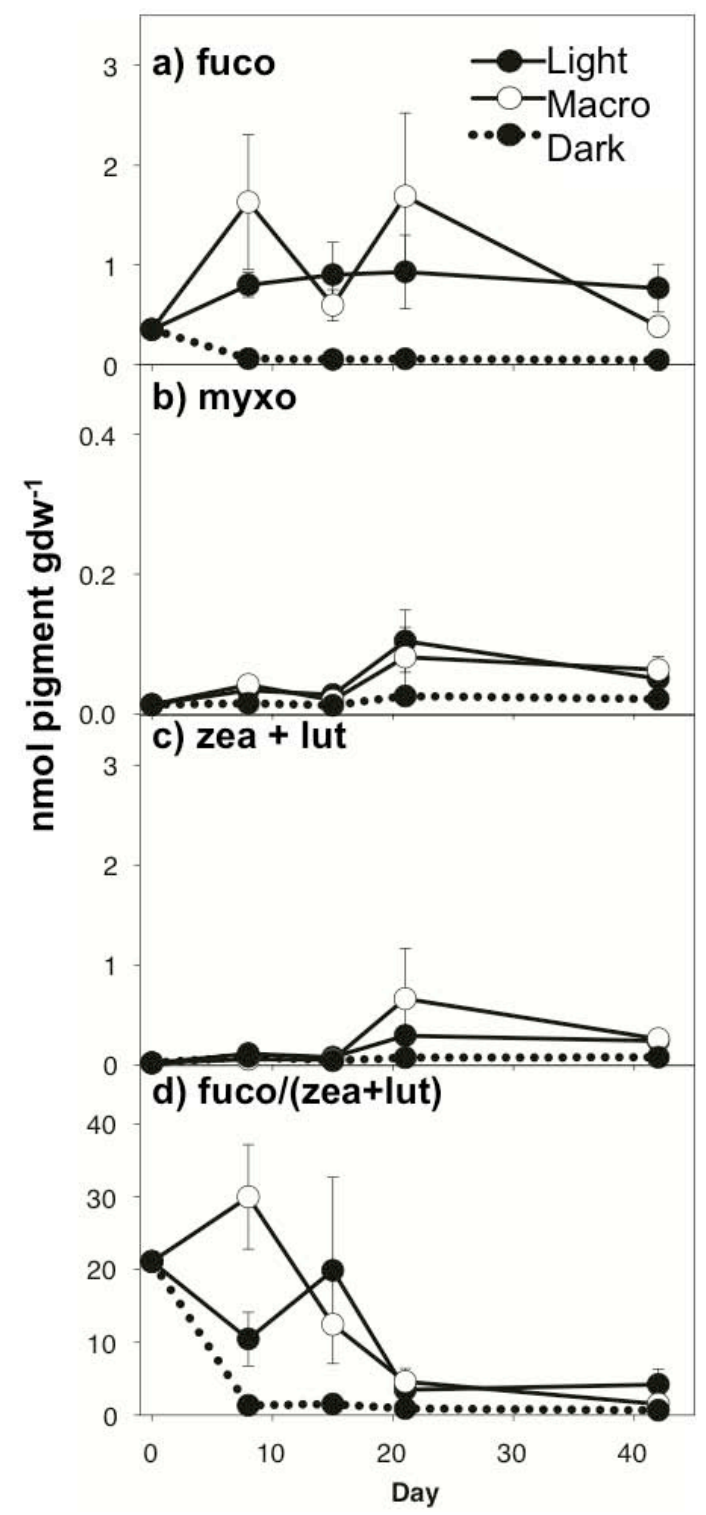

Fig. 6. Concentrations of select accessory pigments in surface (0$0.3 \mathrm{~cm}$ ) sediments. (a-c) are in units of nmol pigment $\mathrm{gdw}^{-1}$. (d) is unitless since it is a ratio of concentrations. Values are mean $\pm \mathrm{SE}$ $(n=4)$.

PC1 and PC2 explained 39.9 and $21.0 \%$ of the variance in PLFA composition, respectively (Fig. 7a and b). PLFA such as 14:0, 16:0, 20:5 $\omega 3$, and 16:1 $\omega 7$, which derive from a variety of aquatic microbes (Table 1), had the most positive loadings on PC1. In contrast, BrFA (bacterial sources), 18:2 $\omega 6$

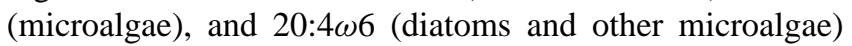
had the most negative loadings on PC1 (Fig. 7b). BrFA and $16: 1 \omega 7$ had negative loadings on $\mathrm{PC} 2$, while polyunsaturated FA (PUFA), typically ascribed to algal sources, had positive loadings on PC2.

Light and Macro treatments grouped closely on Day 1, and had more positive scores than the Dark treatment on PC1 

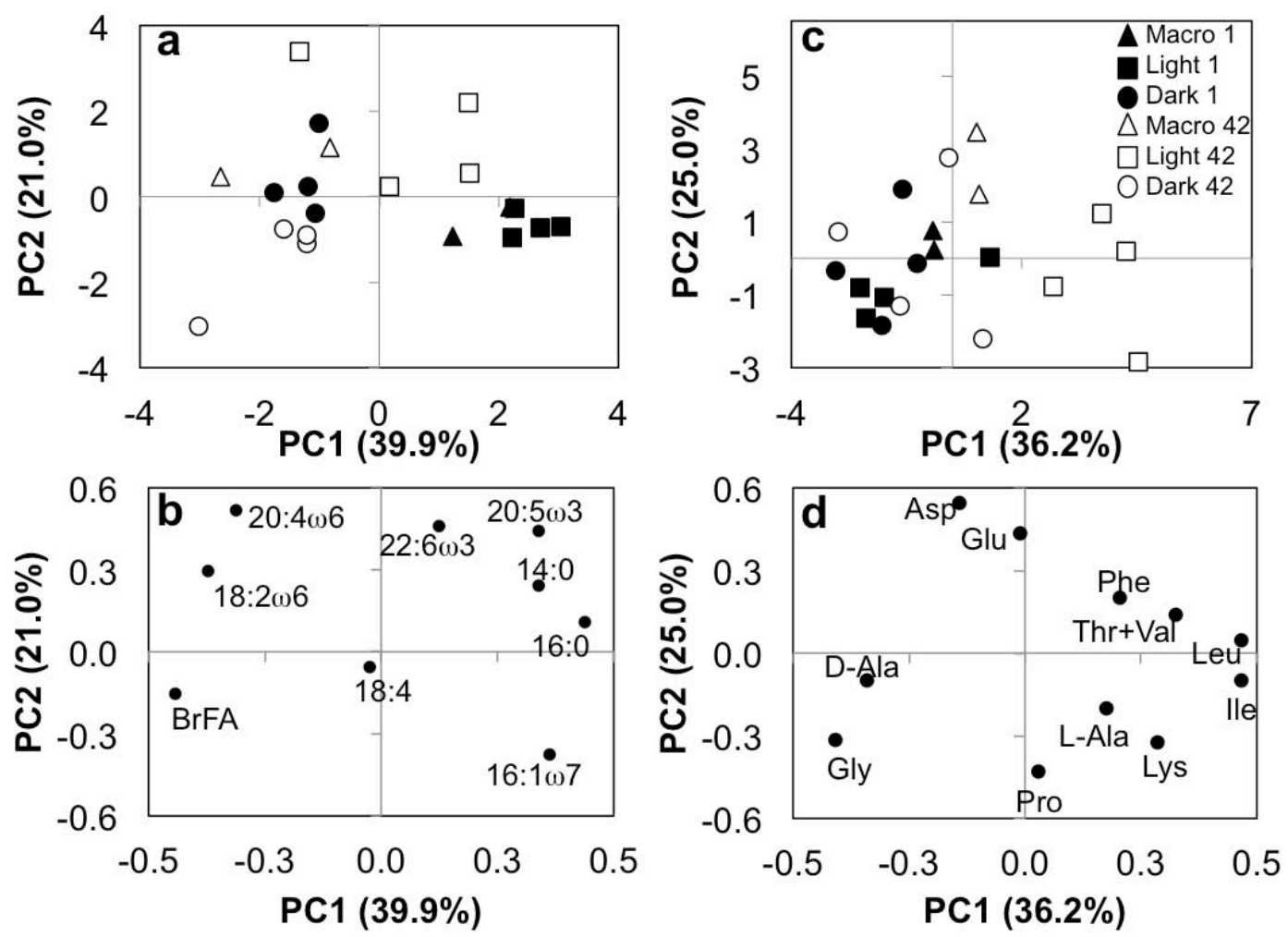

Fig. 7. Score and loading results for PC1 and PC2 from PCA analyses. Scores (a) and loadings (b) for PLFA data and scores (c) and loadings (d) for HAA data are shown. Filled symbols in the score plots represent Day 1 observations and open symbols represent Day 42 . Treatments are Macro (triangles), Light (squares) and Dark (circles). In (b), PLFA such as 14:0, 20:5 $\omega 3$, and 16:1 $\omega 7$, which derive from a variety of aquatic microbes, had the most positive loadings on PC1, while BrFA (bacterial sources) had the most negative loadings on PC1. PUFA had the most positive loadings on PC2. In (d), Leu and Ile had the most positive loadings on PC1 while loadings for Gly and D-Ala (bacteria) were the most negative. Asp and Glu had positive loadings on PC2 while Pro, Gly, and Lys had negative loadings on PC2.

(Fig. 7a). All treatments had similar scores close to the origin along PC2 on Day 1. Over time (Day 42), the treatments diverged from one another and were separated to a greater extent along both PC axes. On Day 42, the light treatments (Light and Macro) had lower scores on PC1 than on Day 1. On Day 42, the treatments were also distributed along PC2, with the Dark treatment having the lowest PC2 scores and Light having the highest.

In a separate analysis of HAA, PC1 and PC2 explained 36.2 and $25.0 \%$ of the variance in HAA composition, respectively (Fig. 7c and d). Mole percentages of Leu and Ile had the most positive loadings on PC1 while loadings for Gly and D-Ala (bacteria) were the most negative (Fig. 7d). Mole percentages of Asp and Glu had positive loadings on PC2 while Pro, Gly and Lys had negative loadings on PC2. Like PLFA, scores along both PC were similar among treatments on Day 1, but diverged by Day 42 (Fig. 7c). While scores for the Dark treatment remained near Day 1 values, both light treatments (Light and Macro) shifted towards more positive scores along PC1 on Day 42. The Light treatments were also separated along PC2 on Day 42: Macro scores for PC2 were higher than Light scores.

\section{Discussion}

Microphytobenthos and benthic macroalgae play an important role in system metabolism within shallow coastal bays. However, their independent and interactive influences on SOM are not well understood. In this study, we demonstrated that changes in autotrophic community structure (e.g., microphytobenthos, ephemeral blooms of macroalgae) that often result from excess nutrient loading can strongly influence SOM quality and quantity, which will ultimately affect its lability and turnover in the system.

\subsection{Role of microphytobenthos}

\subsubsection{Amount and sources of SOM}

To isolate the influence of microphytobenthos on SOM, we compared the Light and Dark treatments in our experimental system. Nearly every sediment parameter we measured showed a clear light-dark difference, demonstrating the significant influence of microphytobenthos on SOM (Table 3). The quantity of SOM increased in Light, as demonstrated by bulk and molecular-level analyses. On a bulk scale, more 
SOM (TOC, TN) accumulated in the Light treatment compared with the Dark treatment (Fig. 2a and b). By Day 42, TOC and TN in the Light increased from baseline values by 173 and $141 \%$, respectively, compared to only 77 and $39 \%$ in the Dark. These light-dark differences were clearly related to microphytobenthic biomass. Chlorophyll $a$ concentrations, which can be considered a proxy for microphytobenthic biomass, were higher in the Light treatment than in the Dark, indicating that microphytobenthic biomass was substantially higher in the Light treatments (Fig. 1b).

Similarly, light-dark differences in THAA and PLFA concentrations also indicated that the presence of microphytobenthos altered SOM composition (Fig. 3a and b). By Day 42 , THAA increased by $180 \%$ relative to background levels in Light treatments compared to a $14 \%$ increase in the Dark. Similarly, PLFA increased by $200 \%$ from background values in Light treatments and actually decreased by $27 \%$ in the Dark. Across treatments, THAA made up a substantial fraction of SOM $(\sim 30-40 \%$ of TN and $12-20 \%$ of TOC; Table 4), similar to the concentration range found during other studies in shallow marine systems (Veuger et al., 2006; Cook et al., 2007). THAA included both living and non-living (detrital) material because HAA have been shown to remain in sediments after cell death (Veuger et al., 2006; Dauwe and Middelburg, 1998; Pantoja and Lee, 2003). PLFA, on the other hand, made up a smaller fraction of TOC $(\sim 1 \%$; Table 4$)$, but represent only viable microbial organic matter because PLFA turnover rapidly after cell death (Parkes, 1987). Therefore, buildup of THAA represented living biomass and detrital buildup while PLFA represented living biomass buildup alone.

Analysis of the PLFA composition lent insight into the composition of the microbial community that developed in the Light and Dark treatments. Not only did PUFA, a general indicator for algal sources of organic matter, increase over time in the Light (Fig. 5a), but PLFA specific to different microalgal communities also showed different patterns over time. For example, 20:5 $\omega 3$, which is specific to diatoms (Table 1), was the most abundant PUFA (Fig. 5d; Supplement Table 3), suggesting that diatoms were the dominant algal class within the surface sediments, which is consistent with surveys of microalgal community composition in temperate systems (Welker et al., 2002; MacIntyre et al., 1996) as well as the pigment data from this experiment, showing fuco to be the most abundant (discussed below). $22: 6 \omega 3$, which was present in lower concentrations than 20:5 $\omega 3$ (Fig. 5g; Supplement Table 3), is also found in diatoms, as well as dinoflagellates. Dinoflagellates, however, do not often contribute significantly to sediment microalgal communities (Barranguet et al., 1997). Other algae that may have been present based on PLFA abundance were green

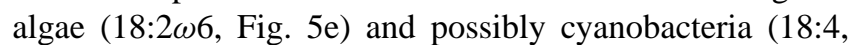
Fig. 5f), both of which have been shown to seasonally dominate microphytobenthic communities in intertidal sediments (Barranguet et al., 1997; Pinckney et al., 1995). However, both of these $\mathrm{C}_{18}$ PUFA can also be present in diatoms, cryptophytes, and dinoflagellates (at trace levels). Based on PLFA data alone, we cannot determine whether green algae and/or cyanobacteria were present; however, the accessory pigment data lend additional insight into the microalgal community within the sediments. The dominant accessory pigment in the $0-0.3 \mathrm{~cm}$ section in the light was fuco (Fig. 6a; Supplemental Table 4), which is specific to diatoms (Table 1). Myxo, the pigment specific to cyanobacteria, was present in low quantities across all treatments, suggesting that cyanobacteria were negligible components of this system (Fig. 6b). Zea + lut, which was dominated by lutein, a pigment found in green algae, were significantly higher in the Light treatments, supporting the conclusion from the PLFA results that green algae were likely present in this system (Fig. 6c).

Over the course of the experiment, there may have been shifts in the algal community structure, as demonstrated by changes in the ratios of 20:5 $\omega 3 / 18: 2 \omega 6$ (Fig. 5h) and fuco/(zea + lut) (Fig. 6d). Decreases in these ratios over time suggest that green algae increased relative to diatoms during the experiment. Previous work has linked changes in algal community structure with changes in nutrient limitation (Sommer, 1996; Pinckney et al., 1995) and temperature (Tilman et al., 1986). Neither temperature, nor $\mathrm{N}$ or phosphorous availability varied over the experiment; however, changes in other nutrients (e.g., silica) may have resulted in the observed shifts in algal composition. Algal species compositions can also change in response to top-down forces such as the feeding preferences of grazers (Duffy and Harvilicz, 2001; Canuel et al., 2007). These shifts were not drastic, however. At the end of the experiment, when concentrations of $\mathrm{C}_{18}$ PUFA and green algal pigments were highest, $\mathrm{C}_{20}$ PUFA and diatom pigments were still more abundant (Figs. $5 \mathrm{c}-\mathrm{d}$ and $6 \mathrm{c}-\mathrm{g}$ ), suggesting that diatoms remained the dominant algal class in this study.

In this experiment, we were able to quantify the contribution of microphytobenthic production to SOM and to characterize the changes in SOM quality that result from microphytobenthic production. Our results are consistent with previous studies, which have investigated the influence of the amount of light, rather than the presence or absence of light, on SOM. For example, Spivak and colleagues (2007) observed increased sediment TOC and TN concentrations in an experimental seagrass system in treatments that received $69 \%$ more light than their shaded treatments. They also observed increased contributions of fatty acids derived from plant and algal sources with increased light, consistent with our PLFA results.

\subsubsection{Lability of SOM and response of the sediment microbial community}

Our work further demonstrates that the lability of SOM changed as a result of the contributions of microphytobenthos in the light. On a bulk level, TN was higher for the Light 
treatment than the Dark treatment (Fig. 2a). Since N is generally the limiting element in temperate marine system, this suggests that the SOM in the light was more labile (available for decomposition) than in the dark. This may have been due to lower levels of THAA in the Dark (Fig. 3a) where THAA contributed a smaller proportion of $\mathrm{N}$ to TN compared with the Light treatments. On the molecular level, changes in THAA composition also indicated changes in organic matter lability. The mole percentages of Leu and Ile were higher in Light whereas Gly was lower (Fig. 4a and c; Supplement Table 4). Dauwe and Middelburg (1998) developed a degradation index (DI) based on amino acid composition, and found that mole percentages of Gly increased and Leu and Ile decreased with increasing degradation. They suggested that selective preservation of structural compounds versus preferential breakdown of cytoplasmic (i.e., not structural) material explained the contrasting behavior of the individual molecules, although more recent studies have presented alternative explanations for similar findings (e.g., Veuger et al., 2012). It was not possible in the present study to calculate the DI because the THAA analyzed in this study (from $\mathrm{GC}$ analysis) does not overlap completely with those analyzed in most other studies, which are HPLC based. The fact that the Dark treatment followed the patterns predicted by the DI suggests that detrital material rather than newly produced biomass (e.g., by microphytobenthos and bacteria in the Light treatment) was the dominant source of SOM in the Dark treatment. Increases in total THAA and PLFA concentrations are also consistent with increased organic matter lability in the Light. The general susceptibility of $\mathrm{N}$-containing amino acids to microbial mineralization and high contributions of THAA to SOM make remineralization of THAA a potentially major source of inorganic $\mathrm{N}$ in sediments (Pantoja and Lee, 2003). Similarly, fatty acids, particularly PUFA, are considered labile and make up an important component of energy flow in benthic food webs (Sun et al., 1997; Canuel et al., 1995; Canuel and Martens, 1996).

These changes in SOM quantity and quality in turn further shaped the sediment microbial community. The presence of labile SOM increased bacterial biomass in the Light treatment compared to the Dark treatment by providing more substrate for bacteria. Bacterial-specific PLFA concentrations were higher in the Light (Fig. 5b), suggesting buildup of heterotrophic bacterial biomass within the sediments. Bacterial PLFA increased in the Dark treatments for the first two weeks of the experiment, but then decreased for the remainder of the experiment, ending on Day 42 with PLFA concentrations below initial values. This suggests that bacteria used up available labile organic matter in the Dark treatments by Day 14 . This may have been exacerbated by the fact that the Dark treatment was maintained in the dark for two weeks prior to the start of the experiment. Previous studies have suggested that bacterial and microphytobenthic activities may be coupled in a number of ways. First, bacteria can directly decompose detrital microphytobenthic material, as has been observed in numerous studies (Cook et al., 2007; Hardison et al., 2011b; Veuger et al., 2007). Thus, microphytobenthic detritus may serve both as a substrate for heterotrophy and as a source of remineralized $\mathrm{N}$ and phosphorus, which may be limited. Second, benthic microalgae, particularly diatoms, excrete extracellular polymeric substances (EPS) that aid in sediment stability and/or motility (Smith and Underwood, 1998; Welker et al., 2002; Taylor and Paterson, 1998), and may also serve as a substrate for bacteria (Middelburg et al., 2000; Hardison et al., 2011b; Evrard et al., 2008; Goto et al., 2001). Lack of bacterial biomass buildup in the Dark treatments, in the absence of photosynthesizing microphytobenthos, suggests that organic matter substrate became limiting after the initial pool of labile organic matter in the sediments was exhausted.

We have additional evidence from a companion benthic flux study suggesting that the autotrophic process of nitrification may have occurred in the Dark (Anderson, unpublished). Results from our flux study showed strong uptake of $\mathrm{NH}_{4}^{+}$into the sediments with almost equal release of $\mathrm{NO}_{3}^{-}$, with an estimated $\mathrm{C}$ fixation that was comparable to the measured increased sediment TOC in the Dark (data not shown). It is also possible that the increased TOC and TN in the Dark was driven by bacterial use of water column DOC and DON, as has been observed in the literature (e.g., Maher and Eyre, 2010, 2011). Although there may have been buildup of TOC and TN in the Dark as a result of any of these mechanisms, overall, TOC and TN in the Light increased relative to baseline values by a much larger percentage compared to in the Dark.

Overall, microphytobenthos fundamentally altered SOM composition in our mesocosm experiment. They produced labile organic matter that supported an active heterotrophic bacterial community and increased the TOC and TN content of the sediments. We likely observed higher microphytobenthic and bacterial abundances in the mesocosms relative to the field because the mesocosm system removed some predation pressure and reduced physical processes such as resuspension and advection. However, the mesocosm experimental system also provided a tremendous opportunity since it is impossible to separate the effects of microphytobenthos from other processes in the field. Since our objective was to compare treatments and assess the differences due to the presence of microphytobenthos, we present these changes as estimates of the potential influence of microphytobenthos on SOM in the environment.

\subsection{Role of benthic macroalgae}

Our second objective was to investigate the influence of a macroalgal bloom on SOM. Light availability is thought to be the primary factor regulating microphytobenthic community growth (Heip et al., 1995; Spivak et al., 2007; Stutes et al., 2006), and benthic macroalgae have the potential to limit light available to microphytobenthos. Floating mats of 
macroalgae reduce light available to benthic autotrophs, and increases in the occurrence and size of blooms of macroalgae have been hypothesized as a factor contributing to global seagrass declines (Hauxwell et al., 2001). Macroalgae have also been shown to "self shade" when light is attenuated within the layers of an algal mat (Peckol and Rivers, 1996; KrauseJensen et al., 1996), and self-shading has been suggested as a possible cause for "crashes" of mid-summer macroalgal blooms that have been observed in numerous systems (Sfriso et al., 1992; McGlathery et al., 2001). Macroalgae were added to the mesocosms at densities observed in HIB and other shallow coastal bays, and their final densities (4fold increase) were within the range of more eutrophied lagoons (McGlathery et al., 2001; Hauxwell et al., 2001; Sfriso et al., 1992; Pregnall and Rudy, 1985). Our intensive sampling throughout the experiment allowed us to track changes between the light treatments with and without macroalgae as the macroalgal bloom developed. We were able to not only detect changes in many of the sediment parameters that suggested that the presence of macroalgae influenced SOM, but were also able to detect the timing of those changes as the macroalgal bloom developed, as discussed below.

Changes in numerous sediment parameters suggested that macroalgae affected SOM quantity. TOC, TN, THAA, and PLFA concentrations were all lower in Macro treatments compared to Light treatments (Figs. 2a, b and 3a, b). By Day 42, SOM accumulation in Macro treatments was intermediate between the Light and Dark treatments. TOC, TN, and THAA increased in Macro treatments from background values by 130,94 , and $97 \%$, respectively. PLFA, on the other hand, increased until $\sim$ Day 14 and then decreased $15 \%$ from initial values by Day 42, similar to the Dark treatments.

Molecular-level analyses also indicated that the macroalgae treatment affected the composition of SOM. PLFA and pigment data in the Macro treatment showed similar patterns in microalgal community composition as the Light treatments. For example, in both treatments, diatoms (as indicated by 20:5 $\omega 3$, fuco; Figs. 5d and 6a) dominated the microalgal community, but there was likely an increase in green algae relative to diatoms over time $(20: 5 \omega 3 / 18: 2 \omega 6$, fuco/(zea + lut); Figs. 5h and 6d), and cyanobacteria (18:4, myxo; Figs. 5f and 6b) were negligible in these sediments. However, the concentrations of total PUFA and individual algal PLFA concentrations were lower in Macro treatments, indicating that macroalgae limited microphytobenthic production (Fig. 5). Changes in PLFA over time in the Macro treatment were likely related to the amount of macroalgal biomass within the mesocosms. By Day 14, macroalgal biomass was $\sim 300 \mathrm{gdw} \mathrm{m}^{-2}$ (Fig. 1). According to a study by Krause-Jensen and colleagues (1996), this is the estimated value above which macroalgae completely block light reaching microphytobenthos. After this critical density in our experiment, microphytobenthic production decreased and SOM built up more slowly in Macro treatments. Even if macroalgal biomass had remained below
$300 \mathrm{gdw} \mathrm{m}^{-2}$, chronic shading by macroalgae would likely have decreased microphytobenthic metabolism, as has been observed in studies investigating the effects of shading on microphytobenthos metabolism (Stutes et al., 2006; Sundback and McGlathery, 2005). It is not uncommon for macroalgal blooms to reach densities above $300 \mathrm{gdw} \mathrm{m}^{-2}$ in eutrophied systems and persist for days to weeks (see Sundback and McGlathery, 2005 and references therein). Based on results from this present study, it is likely that blooms of this magnitude negatively affect microphytobenthic biomass.

As in our light-dark comparison, the presence of macroalgae also changed the quality of SOM. Concentrations of PLFA in Macro treatments remained level after Day 14 (Fig. 3b), and the fraction of TOC from PLFA-C actually decreased, suggesting that production of labile organic matter slowed down compared to the Light treatment (Table 4). As a result of changes in SOM quantity and composition, the heterotrophic bacterial community differed in treatments with macroalgae. The mole fraction of Lys was lower in the Macro treatment with values that were similar to the Dark treatment (Fig. 4b). Lys makes up a notable fraction of THAA in bacteria (5-15\%) (Cowie and Hedges, 1992), so a lower concentration in sediment THAA likely indicated decreased bacterial activity. Additional studies suggest that Lys is selectively degraded due to its simple structure and high $\mathrm{N}$ content (Cowie and Hedges, 1992). Bacterial PLFA concentrations were also lower in Macro treatments throughout most of the experiment (Fig. 5b). However, due to high variability between mesocosms, we were unable to detect a significant effect of macroalgae across treatments (Table 3 ).

Our results demonstrate decreased SOM quantity and quality in Macro treatments compared with Light treatments, suggesting that macroalgae negatively affected sediment microbes. Previous studies show that macroalgae release dissolved organic matter (DOM) while growing and during senescence, which in turn impacts water column $\mathrm{C}$ and $\mathrm{N}$ cycling (e.g., Tyler et al., 2001; Tyler et al., 2003; Maher and Eyre, 2010). This DOM may also diffuse into the sediments and be available to sediment bacteria; however, DOM released by microphytobenthos directly to the sediment porewater would likely be more accessible to the sediment bacterial community than macroalgal DOM released to the overlying water. Indeed, our data suggests that DOM produced by macroalgae was not a direct substitute for the DOM produced by microphytobenthos in the absence of macroalgae. Initially, many of the measured sediment parameters (e.g., TOC, TN, PLFA, etc.) were similar for Macro and Light because both treatments equilibrated (without macroalgae added) for two weeks prior to the experiment in natural day/night conditions and thus began the experiment with an active microphytobenthic community, while the Dark treatment equilibrated for two weeks prior to the experiment in the dark, without an active microphytobenthic community. As the macroalgae grew over the course of the experiment, we observed a divergence in bacterial-specific parameters 
(e.g., BrFA, Fig. 5b) between the Macro and Light treatments beginning $\sim$ Day 14. If macroalgal DOM was of equal importance to sediment microbes as microphytobenthic DOM, we do not believe the observed divergence in these parameters would have occurred.

\subsection{Synthesis}

PCA results provide a summary of the changes in the dominant controls on SOM on Day 1 versus Day 42. On Day 1, PLFA composition in Light and Macro treatments differed from the Dark, which likely reflects the fact that the Dark treatments were incubated in the dark for two weeks prior to the start of the experiment. PLFA composition reflected the contribution of algal fatty acids to SOM in both the Light and Macro treatments relative to the Dark treatment; however, since macroalgae were only present for 1 day, there were no significant effects from macroalgae. On Day 1 HAA composition did not yet differ between any treatments. By Day 42, after macroalgal biomass had increased by fourfold, all treatments displayed a gradient of PLFA and HAA composition. Sediment composition in the Macro treatment shifted away from the Light treatment towards the Dark treatment, with less influence from algal PLFA and the more labile amino acids (e.g., Leu, Ile), and more influence from bacterial PLFA and less labile amino acids (e.g., Gly, D-Ala). In both Light and Macro treatments, we also observed shifts in microphytobenthic community composition by Day 42. On Day 1, $20: 5 \omega 3$ was the most prominent algal PUFA, while algae producing 18:2 $\omega 6$ contributed relatively more to algal PLFA by Day 42.

Overall, microphytobenthos fundamentally altered SOM quality and quantity; however, the role of microphytobenthos as a source of labile SOM was significantly diminished likely due to shading by macroalgae. Although microphytobenthos may compete with macroalgae for nutrients, in our experiment, neither $\mathrm{N}$ nor phosphorous availability varied over the experiment, which suggests competition for nutrients was not the driver of our observed changes. The potential ecological consequences of decreased microphytobenthic production are numerous. For example, biogeochemical processes such as nitrification and denitrification are affected by diel variations in oxygen related to microphytobenthic metabolism as well as competition with microphytobenthos for dissolved N (An and Joye, 2001; Rysgaard et al., 1995). In addition, microphytobenthos are a nutrient-rich food source for numerous faunal grazers (Miller et al., 1996) and to heterotrophic bacteria (Banta et al., 2004). Sediment stability is also enhanced by the presence of benthic diatoms that produce EPS (Tolhurst et al., 2002).

Moreover, the shift from a community dominated by microphytobenthos to macroalgae will change the role of sediments in nutrient cycling. Benthic-pelagic coupling is particularly important in shallow systems, since much of the $\mathrm{C}$ and nutrient cycling occurs at the sediment-water inter- face. Previous studies suggest that tight coupling between microphytobenthos and sediment bacteria serves as a mechanism for retaining $\mathrm{C}$ and $\mathrm{N}$ in the sediments (Hardison et al., 2011b; Evrard et al., 2008). If microphytobenthic production is decreased due to macroalgae, this will in turn decrease this sink, allowing a greater flux of $\mathrm{C}$ and $\mathrm{N}$ from the sediments to the overlying water. Macroalgae take up large amounts of $\mathrm{C}$ and $\mathrm{N}$ while growing. Indeed, our companion flux study showed increased benthic gross primary production in the Macro treatment (sediments + macroalgae) relative to the Light treatment (sediments alone; Anderson, unpublished data). However, retention of $\mathrm{C}$ and $\mathrm{N}$ within the sediments would likely be a more stable sink than retention as bloom-forming macroalgal tissue. Once these ephemeral macroalgae die, nutrients are re-released to the water column, which may fuel phytoplankton and bacterial metabolisms (McGlathery et al. 2001; Tyler et al., 2003). Thus, cycling of $\mathrm{C}$ and $\mathrm{N}$ through macroalgae rather than microphytobenthos may create a positive feedback to eutrophication, whereas sediment microbes may play a key buffering role against the effects of increased nutrient loading. Our results demonstrate that macroalgae significantly altered SOM properties that influence ecosystem processes, and chronic shading by dense macroalgal blooms, characteristic of some eutrophied systems, will likely result in surface sediments that more closely resemble sediments in regions unaffected by light.

\section{Supplementary material related to this article is available online at: http://www.biogeosciences.net/10/ 5571/2013/bg-10-5571-2013-supplement.pdf.}

Acknowledgements. This work would not have been possible without the help of M. Luckenbach, S. Fate, and R. Bonniwell at the Virginia Institute of Marine Science (VIMS) Eastern Shore Lab as well as R. Bushnell, J. Cope, E. Ferer, E. Lerberg, D. Maxey, L. Palomo, S. Salisbury, C. Smith, J. Stanhope, and H. Walker at VIMS. We are also grateful to J. Middelburg and M. Houtekamer at the Netherlands Institute for Sea Research (NIOZ). This research was supported by the National Science Foundation (Virginia Coast Reserve Long-Term Ecological Research project 0080381 and 0621014; Division of Environmental Biology (DEB) Ecosystems Program 0542645 to I. C. Anderson and E. A. Canuel and 0542635 to C. R. Tobias), the European Association of Organic Geochemists (Shell Travel Award to A. K. Hardison), the Environmental Protection Agency (EPA FP916722010 to A. K. Hardison), the Netherlands Organization for Scientific Research (Pionier 833.02.2002 to B. Veuger), and the Darwin Center for Biogeology (project 142.16.1052 to B. Veuger). The EPA has not officially endorsed this publication and the views expressed herein may not reflect the views of the EPA. This paper is Contribution No. 3298 of VIMS, The College of Willliam \& Mary.

Edited by: C. Woulds 


\section{References}

An, S. and Joye, S. B.: Enhancement of coupled nitrificationdenitrification by benthic photosynthesis in shallow estuarine sediments, Limnol. Oceanogr., 46, 62-74, 2001.

Anderson, I. C., McGlathery, K. J., and Tyler, A. C.: Microbial mediation of "reactive" nitrogen transformations in a temperate lagoon, Mar. Ecol.-Prog. Ser., 246, 73-84, 2003.

Banta, G. T., Pedersen, M. F., and Nielsen, S. L.: Decomposition of marine primary producers: Consequences for nutrient recycling and retention in coastal ecosystems, in: Estuarine Nutrient Cycling: The Influence of Primary Producers, edited by: Nielsen, S. L., Banta, G. T., and Pedersen, M. F., Kluwer Academic Publishers, Netherlands, 187-216, 2004.

Barranguet, C., Herman, P. M. J., and Sinke, J. J.: Microphytobenthos biomass and community somposition studied by pigment biomarkers: importance and fate in the carbon cycle of a tidal flat, J. Sea Res., 38, 59-70, 1997.

Benoy, G. A. and Kalff, J.: Sediment accumulation and $\mathrm{Pb}$ burdens in submerged macrophyte beds, Limnol. Oceanogr., 44, 10811090, 1999.

Bligh, E. G. and Dyer, W. J.: A Rapid Method of Total Lipid Extraction and Purification, Can. J. Biochem. Phys., 37, 911-917, 1959.

Boschker, H. T. S., Wielemaker, A., Schaub, B. E. M., and Holmer, M.: Limited coupling of macrophyte production and bacterial carbon cycling in the sediments of Zostera spp. meadows, Mar. Ecol.-Prog. Ser., 203, 181-189, 2000.

Bouillon, S. and Boschker, H. T. S.: Bacterial carbon sources in coastal sediments: a cross-system analysis based on stable isotope data of biomarkers, Biogeosciences, 3, 175-185, doi:10.5194/bg-3-175-2006, 2006.

Canuel, E. A. and Martens, C. S.: Seasonal-Variations in the Sources and Alteration of Organic-Matter Associated with Recently-Deposited Sediments, Org. Geochem., 20, 563-577, 1993.

Canuel, E. A. and Martens, C. S.: Reactivity of recently deposited organic matter: Degradation of lipid compounds near the sediment-water interface, Geochim. Cosmochim. Ac., 60, 17931806, 1996.

Canuel, E. A., Cloern, J. E., Ringelberg, D. B., Guckert, J. B., and Rau, G. H.: Molecular and isotopic tracers used to examine sources of organic matter and its incorporation into the food webs of San Francisco Bay, Limnol. Oceanogr., 40, 67-81, 1995.

Canuel, E. A., Freeman, K. H., and Wakeham, S. G.: Isotopic compositions of lipid biomarker compounds in estuarine plants and surface sediments, Limnol. Oceanogr., 42, 1570-1583, 1997.

Canuel, E. A., Spivak, A. C., Waterson, E. J., and Duffy, J. E.: Biodiversity and food web structure influence short-term accumulation of sediment organic matter in an experimental seagrass system, Limnol. Oceanogr., 52, 590-602, 2007.

Cook, P. L. M., Butler, E. C. V., and Eyre, B. D.: Carbon and nitrogen cycling on intertidal mudflats of a temperate Australian estuary. I. Benthic metabolism, Mar. Ecol.-Prog. Ser., 280, 2538, 2004.

Cook, P. L. M., Veuger, B., Boer, S., and Middelburg, J. J.: Effect of nutrient availability on carbon and nitrogen incorporation and flows through benthic algae and bacteria in near-shore sandy sediment, Aquat. Microb. Ecol., 49, 165-180, 2007.
Cowie, G. L. and Hedges, J. I.: Sources and Reactivities of AminoAcids in a Coastal Marine-Environment, Limnol. Oceanogr., 37, 703-724, 1992.

Dauwe, B. and Middelburg, J. J.: Amino acids and hexosamines as indicators of organic matter degradation state in North Sea sediments, Limnol. Oceanogr., 43, 782-798, 1998.

Dijkman, N. A. and Kromkamp, J. C.: Phospholipid-derived fatty acids as chemotaxonomic markers for phytoplankton: application for inferring phytoplankton composition, Mar. Ecol.-Prog. Ser., 324, 113-125, 2006.

Duarte, C. M.: Submerged Aquatic Vegetation in Relation to Different Nutrient Regimes, Ophelia, 41, 87-112, 1995.

Duffy, J. E. and Harvilicz, A. M.: Species-specific impacts of grazing, amphipods in an eelgrass-bed community, Mar. Ecol.-Prog. Ser., 223, 201-211, 2001.

Evrard, V., Cook, P. L. M., Veuger, B., Huettel, M., and Middelburg, J. J.: Tracing carbon and nitrogen incorporation and pathways in the microbial community of a photic subtidal sand, Aquat. Microb. Ecol., 53, 257-269, 2008.

Fonseca, M. S. and Calahan, J. A.: A preliminary evaluation of wave attenuation by four species of seagrass, Estuar. Coast. Shelf S., 25, 565-576, 1992.

Gacia, E., Duarte, C. M., and Middelburg, J. J.: Carbon and nutrient deposition in a Mediterranean seagrass (Posidonia oceanica) meadow, Limnol. Oceanogr., 47, 23-32, 2002.

Gillan, F. T. and Johns, R. B.: Chemical biomarkers for marine bacteria: fatty acids and pigments, in: Biological Markers in the Sedimentary Record, edited by: Johns, R. B., Elsevier, Amsterdam, 364, 1986.

Goto, N., Mitamura, O., and Terai, H.: Biodegradation of photosynthetically produced extracellular organic carbon from intertidal benthic algae, J. Exp. Mar. Biol. Ecol., 257, 73-86, 2001.

Gray, J. S., Wu, R. S., and Or, Y. Y.: Effects of hypoxia and organic enrichment on the coastal marine environment, Mar. Ecol.-Prog. Ser., 238, 249-279, 2002.

Hardison, A. K., Canuel, E. A., Anderson, I. C., and Veuger, B.: Fate of macroalgae in benthic systems: carbon and nitrogen cycling within the microbial community, Mar. Ecol.-Prog. Ser., 414, 41$55,2010$.

Hardison, A. K., Tobias, C., Stanhope, J., Canuel, E., and Anderson, I.: An Experimental Apparatus for Laboratory and Field-Based Perfusion of Sediment Porewater with Dissolved Tracers, Estuar. Coast., 34, 243-255, 2011 a.

Hardison, A. K., Anderson, I. C., Canuel, E. A., Tobias, C. R., and Veuger, B.: Carbon and nitrogen dynamics in shallow photic systems: Interactions between macroalgae, microalgae, and bacteria, Limnol. Oceanogr., 56, 1489-1503, 2011 b.

Hauxwell, J., Cebrian, J., Furlong, C., and Valiela, I.: Macroalgal canopies contribute to eelgrass (Zostera marina) decline in temperate estuarine ecosystems, Ecology, 82, 1007-1022, 2001.

Hauxwell, J., Cebrian, J., and Valiela, I.: Eelgrass Zostera marina loss in temperate estuaries: relationship to land-derived nitrogen loads and effect of light limiataion imposed by algae, Mar. Ecol.Prog. Ser., 247, 59-73, 2003.

Heck, K. L., Hays, G., and Orth, R. J.: Critical evaluation of the nursery role hypothesis for seagrass meadows, Mar. Ecol.-Prog. Ser., 253, 123-136, 2003.

Hedges, J. I. and Stern, J. H.: Carbon and Nitrogen Determinations of Carbonate-Containing Solids, Limnol. Oceanogr., 29, 657- 
663, 1984

Heip, C., Goosen, N. K., Herman, P., Kromkamp, J. C., Middelburg, J. J., and Soetaert, K.: Production and consumption of biological particles in temperate tidal estuaries, Oceanogr. Mar. Biol., 33, 1-149, 1995.

Jumars, P. A., Eckman, J. E., and Koch, E.: Macroscopic animals and plants in benthic flows, in: The benthic boundary layer, edited by: Boudreau, B. P. and Jorgensen, B. B., Oxford University Press, 320-347, 2001.

Kenworthy, W. J., Zieman, J. C., and Thayer, G. W.: Evidence for the influence of seagrasses on the benthic nitrogen cycle in a coastal plain estuary near Beaufort, North Carolina (USA), Oecologia, 54, 152-158, 1982.

Krause-Jensen, D., McGlathery, K., Rysgaard, S., and Christensen, P. B.: Production within dense mats of the filamentous macroalga Chaetomorpha linum in relation to light and nutrient availability, Mar. Ecol.-Prog. Ser., 134, 207-216, 1996.

Krause-Jensen, D., Christensen, P. B., and Rysgaard, S.: Oxygen and nutrient dynamics within mats of the filamentous macroalga Chaetomorphalinum Estuaries, 22, 31-38, 1999.

Leavitt, P. R. and Hodgson, D. A.: Sedimentary pigments, in: Tracking environmental changes using lake sediments, terrestrial, algal, and siliceous indicators, edited by: Smol, J. P., Birks, H. J. P., and Last, W. M., Kluwer Academic Publishers, Dordrecht, The Netherlands, 2001.

Lee, R. F., Hirota, J., and Barnett, A. M.: Distribution and Importance of Wax Esters in Marine Copepods and Other Zooplankton, Deep-Sea Res., 18, 1147-1165, 1971.

Lorenzen, C. J.: Determination of Chlorophyll and Pheo-Pigments Spectrophotometric Equations, Limnol. Oceanogr., 12, 343-346, 1967.

MacIntyre, H. L., Geider, R. J., and Miller, D. C.: Microphytobenthos: The ecological role of the "secret garden" of unvegetated, shallow-water marine habitats .1. Distribution, abundance and primary production, Estuaries, 19, 186-201, 1996.

Maher, D. T. and Eyre, B. D.: Benthic fluxes of dissolved organic carbon in three temperate Australian estuaries: Implications for global estimates of benthic DOC fluxes, J. Geophys. Res., 115, G04039, doi:10.1029/2010JG001433, 2010.

McGlathery, K. J., Anderson, I. C., and Tyler, A. C.: Magnitude and variability of benthic and pelagic metabolism in a temperate coastal lagoon, Mar. Ecol.-Prog. Ser., 216, 1-15, 2001.

McGlathery, K. J., Sundback, K., and Anderson, I. C.: Eutrophication in shallow coastal bays and lagoons: the role of plants in the coastal filter, Mar. Ecol.-Prog. Ser., 348, 1-18, 2007.

Middelburg, J. J., Barranguet, C., Boschker, H. T. S., Herman, P. M. J., Moens, T., and Heip, C. H. R.: The fate of intertidal microphytobenthos carbon: An in situ C-13-labeling study, Limnol. Oceanogr., 45, 1224-1234, 2000.

Miller, D. C., Geider, R. J., and MacIntyre, H. L.: Microphytobenthos: The ecological role of the "secret garden" of unvegetated, shallow-water marine habitats .2. Role in sediment stability and shallow-water food webs, Estuaries, 19, 202-212, 1996.

Nielsen, S. L., Enriquez, S., Duarte, C. M., and Sand-Jensen, K.: Scaling maximum growth rates across photosynthetic organisms, Funct. Ecol., 10, 167-175, 1996.

Nilsson, P., Jonsson, B., Swanberg, I. L., and Sundback, K.: Response of a Marine Shallow-Water Sediment System to an Increased Load of Inorganic Nutrients, Mar. Ecol.-Prog. Ser., 71,
275-290, 1991.

Nixon, S. W.: Coastal Marine Eutrophication - a Definition, Social Causes, and Future Concerns, Ophelia, 41, 199-219, 1995.

Norkko, A.: The impact of loose-lying algal mats and predation by the brown shrimp Crangon crangon (L.) on infaunal prey dispersal and survival, J. Exp. Mar. Biol. Ecol., 221, 99-116, 1998.

Norkko, J., Bonsdorff, E., and Norkko, A.: Drifting algal mats as an alternative habitat for benthic invertebrates: species-specific responses to a transient resource, J. Exp. Mar. Biol. Ecol., 248, 79-104, 2000.

NRC: National Research Council. Clean coastal waters: understanding and reducing the effects of nutrient pollution, National Academy Press, Washington, DC, 2000

Orth, R. J., Heck, K. L., and van Montfrans, J.: Faunal components in seagrass beds: a review of the influence of plant structure and prey characteristics on predator-prey relationships, Estuaries, 7, 339-250, 1984.

Pantoja, S. and Lee, C.: Amino acid remineralization and organic matter lability in Chilean coastal sediments, Org. Geochem., 34 , 1047-1056, 2003.

Parkes, R. J.: Analysis of microbial communities within sediments using biomarkers, in: Ecology of Microbial Communities, edited by: Hetcher, M., Gray, R. T. G., and Jones, J. G., Cambridge University Press, Cambridge, 147-177, 1987.

Paterson, D. M. and Black, K. S.: Water flow, sediment dynamics, and benthic biology, Adv. Ecol. Res., 29, 155-193, 1999.

Peckol, P. and Rivers, J. S.: Contribution by macroalgal mats to primary production of a shallow embayment under high and low nitrogen-loading rates, Estuar. Coast. Shelf S., 43, 311-325, 1996.

Pedersen, M. F., Nielsen, S. L., and Banta, G. T.: Interactions between vegetation and nutrient dynamics in coastal marine ecosystems: An introduction, in: Estuarine Nutrient Cycling: The Influence of Primary Producers, edited by: Nielsen, S. L., Banta, G. T., and Pedersen, M. F., Kluwer, Dordrecht, 2004.

Pelz, O., Cifuentes, L. A., Hammer, B. T., Kelley, C. A., and Coffin, R. B.: Tracing the assimilation of organic compounds using delta C-13 analysis of unique amino acids in the bacterial peptidoglycan cell wall, FEMS Microbiol. Ecol., 25, 229-240, 1998.

Pinckney, J., Papa, R., and Zingmark, R.: Comparison of HighPerformance Liquid-Chromatographic, Spectrophotometric, and Fluorometric Methods for Determining Chlorophyll a Concentrations in Estuarine Sediments, J. Microbiol. Meth., 19, 59-66, 1994.

Pinckney, J., Paerl, H. W., and Fitzpatrick, M.: Impacts of Seasonality and Nutrients on Microbial Mat Community Structure and Function, Mar. Ecol.-Prog. Ser., 123, 207-216, 1995.

Poerschmann, J. and Carlson, R.: New fractionation scheme for lipid classes based on "in-cell fractionation" using sequential pressurized liquid extraction, J. Chromatogr. A, 1127, 18-25, 2006.

Pregnall, A. M. and Rudy, P. P.: Contribution of green macroalgal mats (Enteromorpha spp.) to seasonal production in an estuary, Mar. Ecol.-Prog. Ser., 24, 167-176, 1985.

Raffaelli, D. G., Raven, J. H., and Poole, L. J.: Ecological impact of green macroalgal blooms, Oceanogr. Mar. Biol., 36, 97-125, 1998.

Risgaard-Petersen, N.: Coupled nitrification-denitrification in autotrophic and heterotrophic estuarine sediments: On the influence 
of benthic microalgae, Limnol. Oceanogr., 48, 93-105, 2003.

Rysgaard, S., Christensen, P. B., and Nielsen, L. P.: SeasonalVariation in Nitrification and Denitrification in Estuarine Sediment Colonized by Benthic Microalgae and Bioturbating Infauna, Mar. Ecol.-Prog. Ser., 126, 111-121, 1995.

Sand-Jensen, K. and Borum, J.: Interactions among phytoplankton, periphyton, and macrophytes in temperate freshwaters and estuaries, Aquat. Bot., 41, 137-175, 1991.

Sfriso, A., Pavoni, B., Marcomini, A., Raccanelli, S., and Orio, A. A.: Particulate Matter Deposition and Nutrient Fluxes onto the Sediments of the Venice Lagoon, Environ. Technol., 13, 473483, 1992.

Smith, D. J. and Underwood, G. J. C.: Exopolymer production by intertidal epipelic diatoms, Limnol. Oceanogr., 43, 1578-1591, 1998.

Sommer, U.: Nutrient competition experiments with periphyton from the Baltic Sea, Mar. Ecol.-Prog. Ser., 140, 161-167, 1996.

Spivak, A. C., Canuel, E. A., Duffy, J. E., and Richardson, J. P.: Topdown and bottom-up controls on sediment organic matter composition in an experimental seagrass ecosystem, Limnol. Oceanogr., 52, 2595-2607, 2007.

Stutes, A. L., Cebrian, J., and Corcoran, A. A.: Effects of nutrient enrichment and shading on sediment primary production and metabolism in eutrophic estuaries, Mar. Ecol.-Prog. Ser., 312, 29-43, 2006.

Sun, M. Y., Wakeham, S. G., and Lee, C.: Rates and mechanisms of fatty acid degradation in oxic and anoxic coastal marine sediments of Long Island Sound, New York, USA, Geochim. Cosmochim. Ac., 61, 341-355, 1997.

Sundback, K. and McGlathery, K. J.: Interactions between benthic macro- and microalgae in the marine environment, in: Interactions between macro- and microorganisms in marine sediments, edited by: Kristensen, E., Kostka, J. E., and Haese, R. H., American Geophysical Union, 2005.

Sundback, K., Nilsson, P., Nilsson, C., and Jonsson, B.: Balance between autotrophic and heterotrophic components and processes in microbenthic communities of sandy sediments: A field study, Estuar. Coast. Shelf S., 43, 689-706, 1996.

Taylor, I. S. and Paterson, D. M.: Microspatial variation in carbohydrate concentrations with depth in the upper millimetres of intertidal cohesive sediments, Estuar. Coast. Shelf S., 46, 359-370, 1998.

Thomsen, M. S., McGlathery, K. J., and Tyler, A. C.: Macroalgal distribution patterns in a shallow, soft-bottom lagoon, with emphasis on the nonnative Gracilaria vermiculophylla and Coldium fragile, Estuar. Coast., 29, 465-473, 2006.

Tilman, D., Kiesling, R., Sterner, R., Kilham, S. S., and Johnson, F. A.: Green, Bluegreen and Diatom Algae - Taxonomic Differences in Competitive Ability for Phosphorus, Silicon and Nitrogen, Arch. Hydrobiol., 106, 473-485, 1986.

Tolhurst, T. J., Gust, G., and Paterson, D. M.: The influence of an extracellular polymeric substance (EPS) on cohesive sediment stability, in: Fine Sediment Dynamics in the Marine Environment, edited by: Winterwerp, J. C., and Kranenburg, C., Elsevier, San Diego, 2002.
Tyler, A. C., McGlathery, K. J., and Anderson, I. C.: Macroalgae mediation of dissolved organic nitrogen fluxes in a temperate coastal lagoon, Estuar. Coast. Shelf S., 53, 155-168, 2001.

Tyler, A. C., McGlathery, K. J., and Anderson, I. C.: Benthic algae control sediment-water column fluxes of organic and inorganic nitrogen compounds in a temperate lagoon, Limnol. Oceanogr., 48, 2125-2137, 2003.

Valiela, I., Foreman, K., Lamontagne, M., Hersh, D., Costa, J., Peckol, P., Demeoandreson, B., Davanzo, C., Babione, M., Sham, C. H., Brawley, J., and Lajtha, K.: Couplings of Watersheds and Coastal Waters - Sources and Consequences of Nutrient Enrichment in Waquoit Bay, Massachusetts, Estuaries, 15, 443-457, 1992.

Valiela, I., McClelland, J., Hauxwell, J., Behr, P. J., Hersh, D., and Foreman, K.: Macroalgal blooms in shallow estuaries: Controls and ecophysiological and ecosystem consequences, Limnol. Oceanogr., 42, 1105-1118, 1997.

Veuger, B., Middelburg, J. J., Boschker, H. T. S., and Houtekamer, M.: Analysis of $\mathrm{N}-15$ incorporation into D-alanine: A new method for tracing nitrogen uptake by bacteria, Limnol. Oceanogr.-Methods, 3, 230-240, 2005.

Veuger, B., van Oevelen, D., Boschker, H. T. S., and Middelburg, J. J.: Fate of peptidoglycan in an intertidal sediment: An in situ C-13-labeling study, Limnol. Oceanogr., 51, 1572-1580, 2006.

Veuger, B., Eyre, B. D., Maher, D., and Middelburg, J. J.: Nitrogen incorporation and retention by bacteria, algae, and fauna in a subtropical intertidal sediment: An in situ N-15-labeling study, Limnol. Oceanogr., 52, 1930-1942, 2007.

Veuger, B., van Oevelen, D., and Middelburg, J. J.: Fate of microbial nitrogen, carbon, hydrolysable amino acids, monosaccharides, and fatty acids in sediment, Geochim. Cosmochim. Ac., 83, 217-233, 2012.

Viso, A. C. and Marty, J.-C.: Fatty acids from 28 marine microalgae, Phytochemistry, 34, 1521-1533, 1993.

Volkman, J. K., Jeffrey, S. W., Nichols, P. D., Rogers, G. I., and Garland, C. D.: Fatty-Acid and Lipid-Composition of 10 Species of Microalgae Used in Mariculture, J. Exp. Mar. Biol. Ecol., 128, 219-240, 1989.

Volkman, J. K., Revill, A. T., Holdsworth, D. G., and Fredericks, D.: Organic matter sources in an enclosed coastal inlet assessed using lipid biomarkers and stable isotopes, Org. Geochem., 39, 689-710, 2008.

Welker, C., Sdrigotti, E., Covelli, S., and Fagan, J.: Microphytobenthos in the Gulf of Trieste (Northern Adriatic Sea): Relationship with Labile Sedimentary Organic Matter and Nutrients, Estuar. Coast. Shelf S., 55, 259-273, 2002.

Wolfstein, K., de Brouwer, J. F. C., and Stal, L. J.: Biochemical partitioning of photosynthetically fixed caarbon by benthic diatoms during short-term incubatiions at different irradiances, Mar. Ecol.-Prog. Ser., 245, 21-31, 2002.

Yunker, M. B., Belicka, L. L., Harvey, H. R., and Macdonald, R. $\mathrm{W}$.: Tracing the inputs and fate of marine and terrigenous organic matter in Arctic Ocean sediments: A multivariate analysis of lipid biomarkers, Deep-Sea Res. Pt. II, 52, 3478-3508, 2005. 